\title{
Evidence for the breakdown of an Angkorian hydraulic system, and its historical implications for understanding the Khmer Empire
}

\author{
Terry Lustig ${ }^{\mathrm{a}, *, 1}$, Sarah Klassen ${ }^{\mathrm{b}}$, Damian Evans ${ }^{\mathrm{c}}$, Robert French ${ }^{\mathrm{d}}$, Ian Moffat ${ }^{\mathrm{e}}$ \\ a Department of Archaeology, University of Sydney, NSW 2006, Australia \\ ${ }^{\mathrm{b}}$ School of Human Evolution and Social Change, Arizona State University, $900 \mathrm{~S}$ Cady Mall, Tempe, AZ 85281, United States \\ ${ }^{\mathrm{c}}$ École française d'Extrême-Orient, 22 Avenue du Président Wilson, Paris 75116, France \\ d Independent Scholar, 30 Woodlands Rd, Ashbury, NSW 2193, Australia \\ e Department of Archaeology, Flinders University, Bedford Park, SA 5042, Australia
}

\section{A R T I C L E I N F O}

\section{Keywords:}

Angkor

Archaeology

Engineering practice

Koh Ker

Lidar

Palaeohydrology

Trial and error

Water management

\begin{abstract}
A B S T R A C T
This paper examines the construction and design of a 7-km long embankment, probably built for King Jayavarman IV between 928 and 941 CE, as part of a new capital. We calculate that the capacities of the outlets were too small, and conclude that the embankment failed, probably within a decade of construction, so that the benefits of the reservoir stored by the embankment and the access road on top of it were lessened substantially. We explain how the design was sub-optimal for construction, and that while the layout had a high aesthetic impact, the processes for ensuring structural integrity were poor. Simple and inexpensive steps to secure the weir were not undertaken. We speculate that this early failure may have contributed to the decision to return the royal court and the capital of the Khmer Empire to the Angkor region, marking a critically important juncture in regional history.
\end{abstract}

\section{Introduction}

With the Angkorian state having lasted for more than six centuries (9th to 15 th centuries CE), scholars have long sought to understand what contributed to its sustainability and what led to its eventual decline (Evans et al., 2007; Fletcher et al., 2008; Groslier, 1979; Groslier, 2007). We suggest that some insights might be gained from studying what happened at Koh Ker, another Khmer political centre about $80 \mathrm{~km}$ ENE of Angkor (Fig. 1). There is mounting evidence from archaeological excavation and survey for a long and complex history of occupation at Koh Ker (Evans, 2010-2011), but it is clear that the city was very short-lived as the centre of Khmer power, lasting only about 17 years as the capital, from 928 to 944 CE.

Jayavarman IV, the first recorded ruler at Koh Ker, was established there no later than 921 CE (Cœdès, 1931, 13; Cœdès, 1937, 50), while Harśovarman I (910-925 CE) and Iśanavarman I (925-928 CE), the sons of Yaśovarman I, his uncle by marriage, were still enthroned at Angkor (Coedès, 1953, 98, 147). The first inscriptions to attest to Jayavarman's power over the Khmer realm do not appear until $928 \mathrm{CE}$ (Cœè̀s, 1931, 13-16). Despite much debate on the topic (e.g., Cœdès, 1931, 16; Jacques, 1971, 169), it is now generally recognized that Jayavarman was likely a legitimate heir to the throne, not a usurper (Vickery, 1986, 108). ${ }^{2}$ While it is yet to be agreed why the political center shifted to Koh Ker, for this paper, we are seeking factors that might help explain why its time there was so short.

It is clear from the inscriptions (Cœè̀s, 1937, 68) that Jayavarman constructed Prasat Thom during this period, its pyramid being the tallest in the Khmer world at the time (Cœelès, 1937, 70). As well, just to

Abbreviations: APHRODITE, Asian Precipitation - Highly Resolved Observational Data Integration Towards Evaluation (of Water Resources); ARI, annual recurrence interval; ASL,

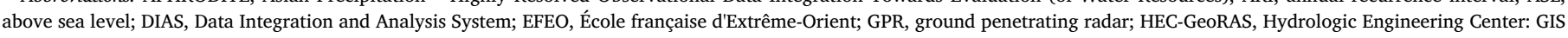

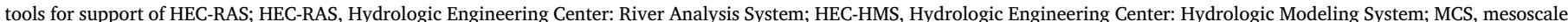
convective system; RMSE, root mean square error; SRTM, NASA Shuttle Radar Topography Mission; TRMM, Tropical Rainfall Measuring Mission

* Corresponding author at: 15 Cottenham Ave, Kensington, NSW 2033, Australia.

E-mail address: terry@environmentalmanagement.com.au (T. Lustig).

${ }^{1}$ Present address, 15 Cottenham Ave, Kensington, NSW 2033, Australia.

${ }^{2}$ That Yaśovarman's two sons succeeded him may have been contrary to the rules of succession of the "conical clan", in which all members are ranked hierarchically in terms of

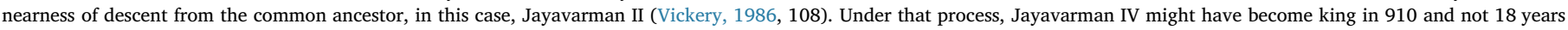
later. 


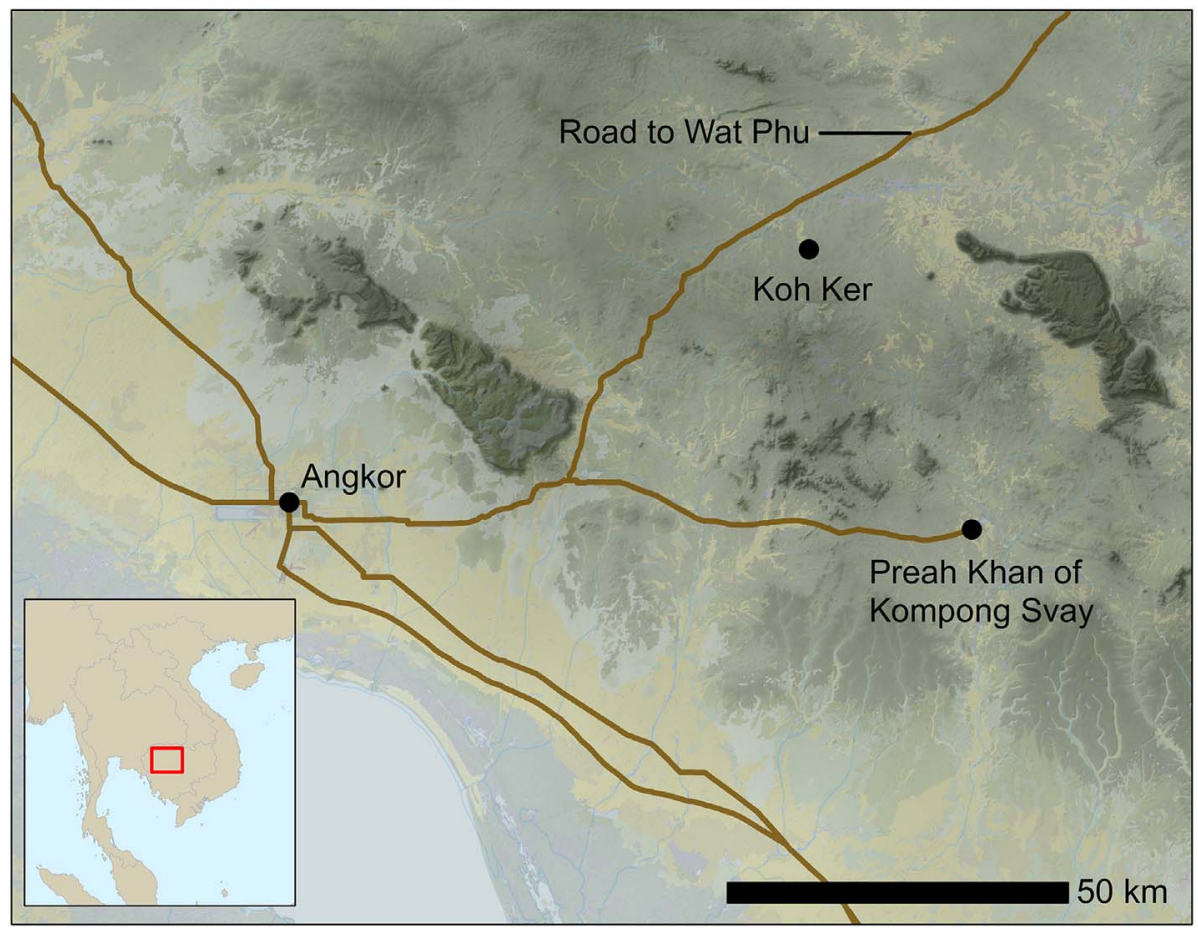

Fig. 1. Koh Ker on the road between Angkor in present-day Cambodia and Wat Phu in southern Laos. Road alignments from Hendrickson (2007).

the north of Prasat Thom, he built a 7-km long weir across the original Rongea River valley (Evans, 2010-2011), the longest water-management structure across a river valley in Khmer history (Fig. 2). ${ }^{3}$ The embankment evidently provided both a level link to the Angkorian highway to Wat Phu in today's southern Laos and created the largest known Angkorian-era artificial lake (Fig. 3).

Just south of the main spillway are the remains of a small temple, now known as Prasat Boeng Voeng. Its western portal has an inscription, K. 823, dated 863 śaka or 941 CE (Jacques, 2014, 350). ${ }^{4}$ The temple has a causeway linking it to the embankment. Our investigations were limited because the area is known to have landmines. However, we could see from the lidar that the level of the crest of the middle of the causeway is lower than the level of the crest of the embankment. This lower level probably results from continual erosion by water draining through it to the north (Fig. 4), and it is reasonable to suppose that it was originally at the same level as the main embankment. The main embankment would not have been built to match the level of the temple causeway, but the other way around. On the assumption that the temple was built at the same time as its causeway, this implies that the main embankment was constructed no later than $941 \mathrm{CE}$. While it is probable that the work to build the main embankment could have only been undertaken by a king, further archaeological investigation of the causeway is required to help verify that the northern reservoir and access road were built before 941 CE, presumably by Jayavarman IV.

But this infrastructure was not to last. Whereas the Rongea River originally ran eastwards past Point A in Fig. 2, we see that it now runs northwards, having overtopped and broken through the embankment at Point B. Once this happened, the large lake, the unimpeded access road, and any economic benefits from the reservoir would have been lost. Did this happen before the political centre moved back to Angkor, and were the two events linked?

\footnotetext{
${ }^{3}$ There were indeed longer Angkorian structures across rivers, such as an embankment about $30 \mathrm{~km}$ long at Angkor, but these were built on the Puok-Siem Reap Delta, where the flows were distributed into many channels, the slopes were shallower, and the water flowed more slowly, making it much easier to control.

${ }^{4}$ The date in the inscription in the eastern portal had been erased by the time it was recorded (Coedès, 1954, 113), so all we know is that the temple was built no later than 941 CE.
}

\section{Site investigations}

It is necessary to understand how the embankment was designed, to understand how soon it overtopped. We will first examine deficiencies in the design of the embankment and the two outlets, and then assess the risk of overtopping by evaluating the flow of water into and out of the reservoir.

\subsection{Methods}

The bare-earth digital terrain model (DTM) we used was generated from airborne laser scanning (lidar) data acquired in a 2012 aerial campaign. The process used to generate the DTM is described in Evans et al. (2013). The elevations given as "above sea level" (ASL) in this paper are recorded or inferred from the lidar-derived DTM or from the processed lidar point cloud. According to the data specifications for the lidar, absolute vertical accuracy is $\pm 0.15 \mathrm{~m}$ RMSE (root mean square error) although data quality achieved was far superior to this specification in most cases, and relative accuracy of points nearby is in the order of cm-level.

We investigated the spillway (Section 2.5.1) on site by clearing it of grass and shrubs, and surveying the laterite surface with a total station to mm-accuracy. Where we suspected blocks were covered with soil, we located them with $1.5 \mathrm{~cm}$ diameter steel rods hammered into the ground to see if they encountered laterite over an informal grid pattern, and positioned with the total station, noting the depth to refusal. The probes could reach to about $1.8 \mathrm{~m}$ below ground. Laterite blocks that were washed downstream were located with a handheld GPS unit to $\sim 10 \mathrm{~m}$ accuracy. Where the blocks were in piles, only the boundaries of the piles were surveyed using the GPS unit.

The chute was cleared of grass and shrubs from $10 \mathrm{~m}$ upstream of the within-chute structures located on the lidar (Section 2.5.2) down to the downstream end of the sloping ground, taken to be the toe of the chute's spillway. Where only a thin layer of soil covered laterite blocks, this was removed, particularly in the area around the pavement and the upstream end of the chute's spillway. Four trenches were excavated at the chute to elicit the extent and form of the structures and the type of damage they had suffered. As this was a water management feature, 


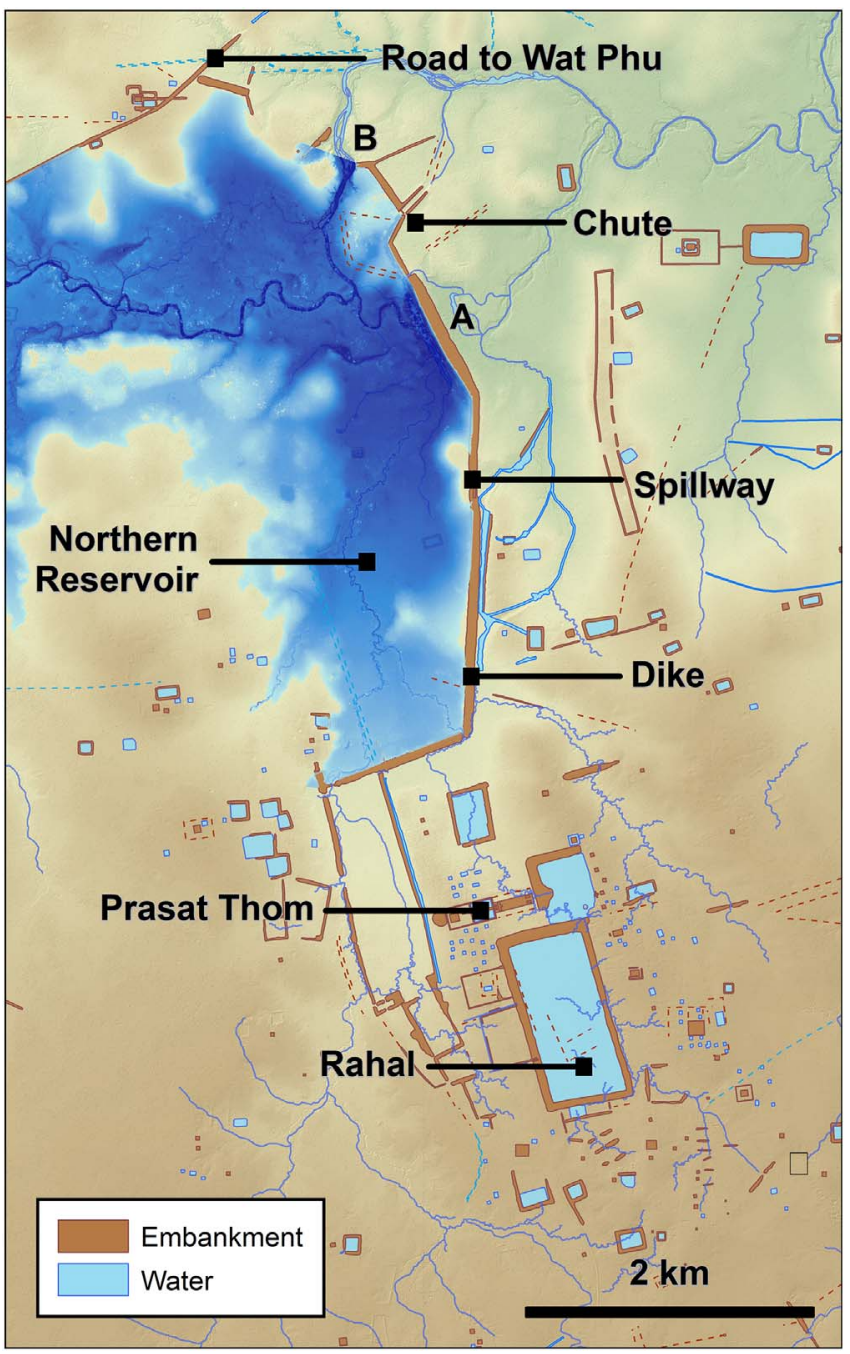

Fig. 2. Weir to north of Prasat Thom. It had two outlets, a spillway $190 \mathrm{~m}$ across, and a chute $230 \mathrm{~m}$ long with 4-m high walls $35 \mathrm{~m}$ apart. Note the N-S linear feature $1 \mathrm{~km}$ to the east of the main spillway. Imagery derived from KALC lidar data (Evans et al., 2013).

very few artifacts were expected or found, so excavations proceeded by arbitrary thicknesses of spits. The site was located in a zone noted as possibly having landmines. As a result, we checked the site with a metal detector before clearing the topsoil. The Cambodian Mine Action Centre (CMAC) also checked the area for landmines deeper than $30 \mathrm{~cm}$ before we began excavating. We probed the area on a rough grid pattern as with the main spillway. We surveyed the laterite and probing points with the total station.

Ground penetrating radar (GPR), summarized for archaeological applications by Conyers (Conyers, 2013), was used to assess the depth to laterite blocks within the chute. ${ }^{5}$ We collected ground penetrating radar data with a Malå X3M with a $500 \mathrm{MHz}$ antenna. Data was collected with a time window of $104 \mathrm{~ns}, 1024$ samples, two stacks and a trace interval of $2 \mathrm{~cm}$. GPR was collected with $1 \mathrm{~m}$ lines spacing on a local grid defined by measuring tapes. Grid corners were positioned with a CHC X90 + static GPS post-processed with Auspos, and the grid topography was measured using photogrammetry data from a DJI Phantom 4 processed using Agisoft Photoscan Professional. GPR data was processed using ReflexW.

\footnotetext{
${ }^{5}$ GPR works by transmitting radar energy, which reflects off subsurface discontinuities in dielectric permittivity. By measuring the time taken for this energy to return to the instrument, the depth of imaged features can be estimated and the measurements can be combined to present the data in one, two or three dimensions.
}

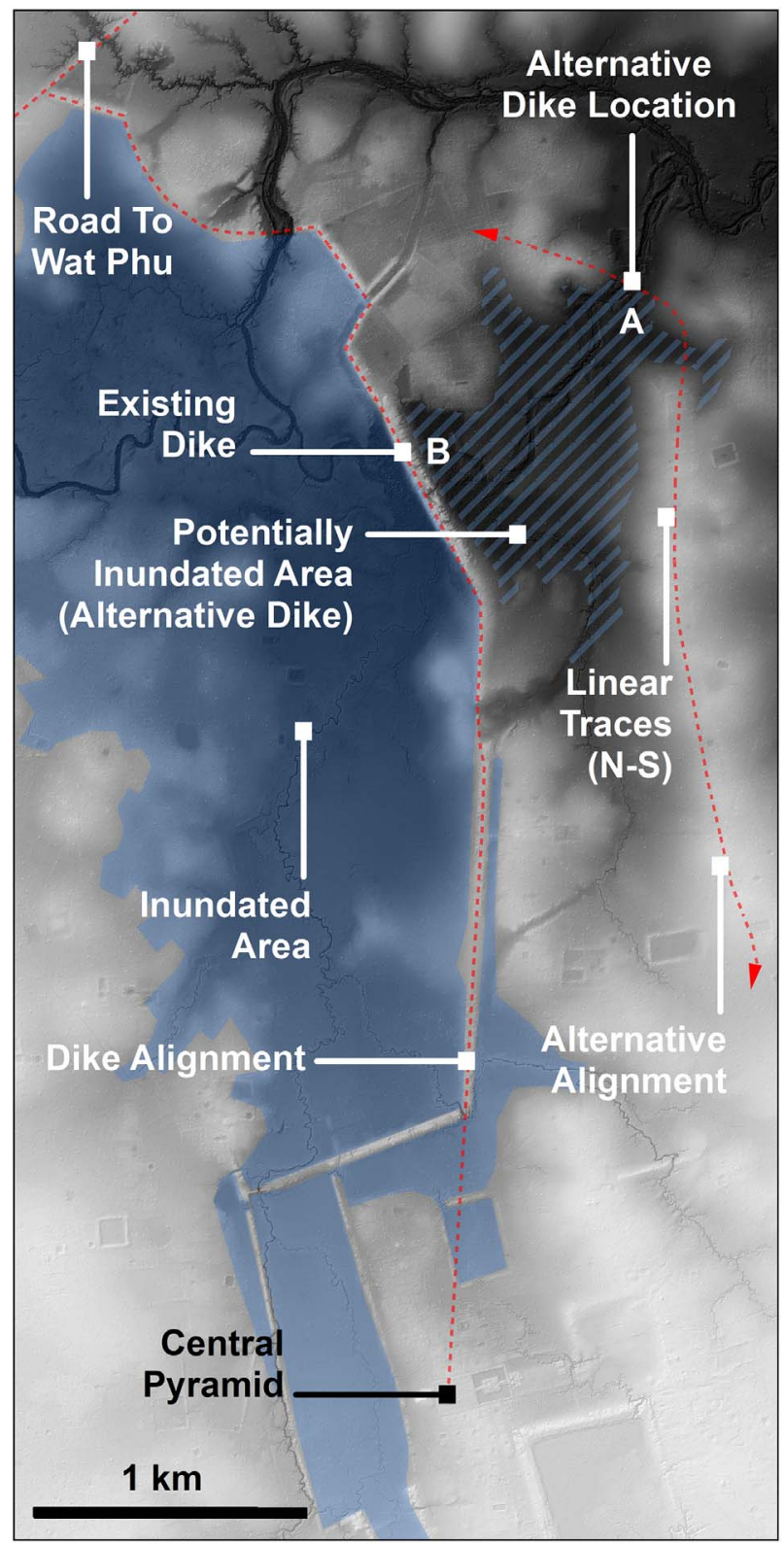

Fig. 3. Access road to Koh Ker past artificial lake formed by weir. The alternative dike location at A, to the north of the linear traces on high ground, would have been less costly to construct than the existing dike B. These linear traces indicate that an alternative access route was under active consideration. (The whiter the color, the highher the ground.)

Using information on river heights from local inhabitants, synthetic rainfall data, pluviometric records, and wind records, we developed preliminary hydraulic, hydrological and wave models for the Stung Rongea and the reservoir formed by the embankment. For the hydraulic modeling, we developed a 1-dimensional hydraulic model of the river using HEC-RAS and HEC-GeoRAS (Ackerman, 2012; Warner et al., 2009). To help ground truth our hydraulic models for flows in this valley, we compared our results with those obtained from observation. Local villagers have a wealth of knowledge of the landscape and rainforest they inhabit. For example, individuals could note changes in the color of bark caused by inundation and cuts into trees made by fishermen to indicate the highest level reached by the floods in 2014 . Additionally, flooding levels dictate where villagers could plant certain crops. Our informants consistently remarked that the 2013 flood had been the highest ( $\sim 67 \mathrm{~m}$ ASL on the upstream side of the embankment) in ten years and the 2014 flood level was the lowest ( $\sim 65 \mathrm{~m} \mathrm{ASL})$. On the downstream side of the embankment, the range of reported levels 


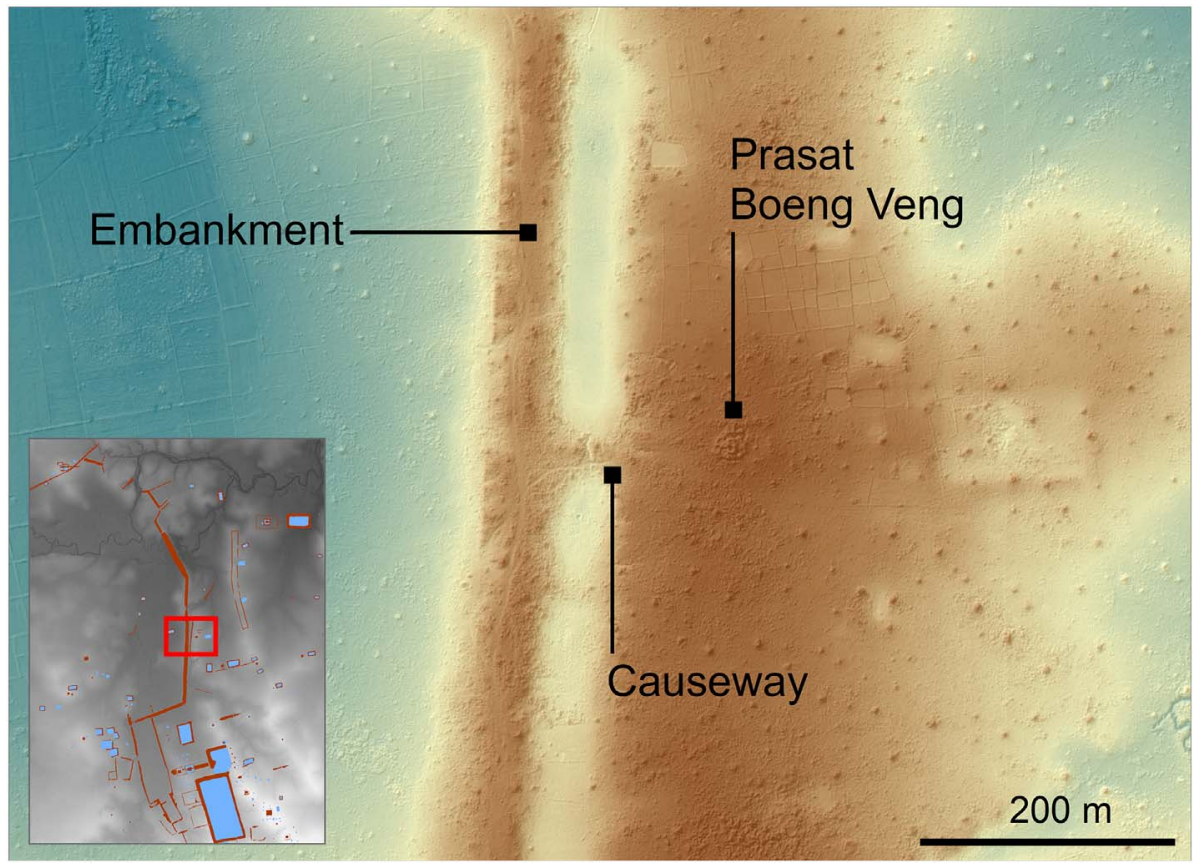

Fig. 4. Prasat Boeng Voeng linked to main embankment by causeway. Water has cut a channel through the causeway, and would have flowed every rainy season. (High elevation is brown, low elevation is blue.)

varied between $\sim 63 \mathrm{~m}$ ASL and $\sim 62.5 \mathrm{~m}$ ASL. We appreciate that memories of such events may be unreliable, yet the consistency of what was reported to us during interviews gives us some confidence in the levels we have adopted for our preliminary modeling. We modeled the capacity of the chute and the spillway to discharge flood flows using well-established relationships for an ogee-crest form of the two spillways (e.g., (Chanson, 2004), 399-403).

For the hydrological modeling, we have used modern meteorological data, such as is available, since we do not have hydroclimatic reconstructions for the 10th century $\mathrm{CE}$ in this area and there is no reliable contemporary data regarding flows for the region. We calculated the 1-, 3- and 7-day floating mean daily rainfalls ${ }^{6}$ from the values modeled for Koh Ker by the APHRODITE project for the years 1980 to 2007 (DIAS, 2010, accessed 2013 and 2017). Since we were only testing the feasibility of overtopping by flood flows, we felt that only preliminary modeling was necessary for this initial investigation. ${ }^{7}$ The 7day floating mean rainfall was taken to model the flows during the early or late periods of the rainy season, when the ground was less saturated than during the peak. The 3-day floating mean rainfall was judged to be suitable for allowing for lags in the rainfall and runoff over the whole catchment during the month of heaviest rainfall, usually September. According to local people, the peak level lasts for about a week, and we took the 1-day rainfall as appropriate for estimating the peak week in the reservoir. For each model, we also subtracted the 10-day average daily evapotranspiration measured from Nobuhiro et al. (Nobuhiro et al., 2009) referred to above. We judged that since evapotranspiration was already low during the rainy season, the year-to-year variations for the month of peak rainfall should not be significant. Infiltration was ignored, as it should not be appreciable for the peak month, and certainly not during a peak day. ${ }^{8}$ The peak inflow to the reservoir was then calculated as this net average precipitation multiplied by the catchment area, on the assumption that the catchment would be saturated and the losses virtually zero. The flood frequency for each year's peak flow was

\footnotetext{
${ }^{6}$ For example, the 3-day floating rainfall was taken as the average rainfall for the three previous days.

${ }^{7}$ More rigorous hydrological modeling, such as by using HEC-HMS (Scharffenberg, 2012) is envisaged for the next stage of investigation.

${ }^{8}$ Strictly speaking, infiltration should have been accounted for with the 7-day model, but an overestimate in this case was judged not to be sufficiently important to justify the effort.
}

calculated using the plotting-position method (e.g., (Langbein, 1960), 48) to obtain relationships for flow against annual recurrence interval (ARI). These were plotted in Microsoft Excel to obtain a semi-logarithmic trendline, which was taken as the flood-frequency relationships for the 1-, 3- and 7-day flows.

When the water level in the reservoir is higher than the level of the crest of the chute spillway, there is an additional volume of water stored temporarily in the reservoir. Thus, if the flow into the reservoir increases after a storm, some extra flow will discharge over the spillways, but some will stay in the reservoir and cause the level of the reservoir to rise. To allow for this in the modeling, one needs to know the relationship between the elevation of the reservoir and the volume stored. This had to be estimated in two parts. The eastern part, which was covered by the lidar, could be measured straightforwardly using ArcGIS to plot contours and then measure the area at each elevation. To the west, the only information on elevation was from the SRTM data (CGIAR-CSI, n.d.), which provides heights for points on a $30-\mathrm{m}$ grid. Such points may be anywhere between ground level or the tops of trees. We assessed the applicability of these elevations using Google Earth. Using these elevations proved not to be such an issue, because many areas that could be counted as part of the reservoir were open fields on river flats, which are being used today for growing rice. The inflows to the reservoir were modeled for each year at 3-hour intervals, assuming uniform inflow over each day. The resulting reservoir level was used to estimate outflow through the chute and over the spillway (a slightly conservative method for rising water levels).

To estimate how much the reservoir level might have dropped below the level of the crest of the spillway in the chute during the dry season, we took the evapotranspiration rate for forests to be about $3.5 \mathrm{~mm} / \mathrm{d}$ in that period, as in Kompong Thom Province $175 \mathrm{~km}$ away (Nobuhiro et al., 2009, 330). We allowed a crop coefficient of 1.15 for a dry environment with light to moderate winds, and added a conservative $20 \%$ to allow for heat transfer from the reservoir to the atmosphere (Finch \& Calver, 2008, 25). We took the river flow to be zero, as we had observed for this time of the year, and assumed that the groundwater seepage was not significant for this landscape, at least some of which is underlain by sandstone at depths of less than $3 \mathrm{~m}$ (Evans, 2010-2011, 101-2).

The velocity of a flood wave in the main channel of the river upstream of the reservoir was estimated by assuming a velocity of about 


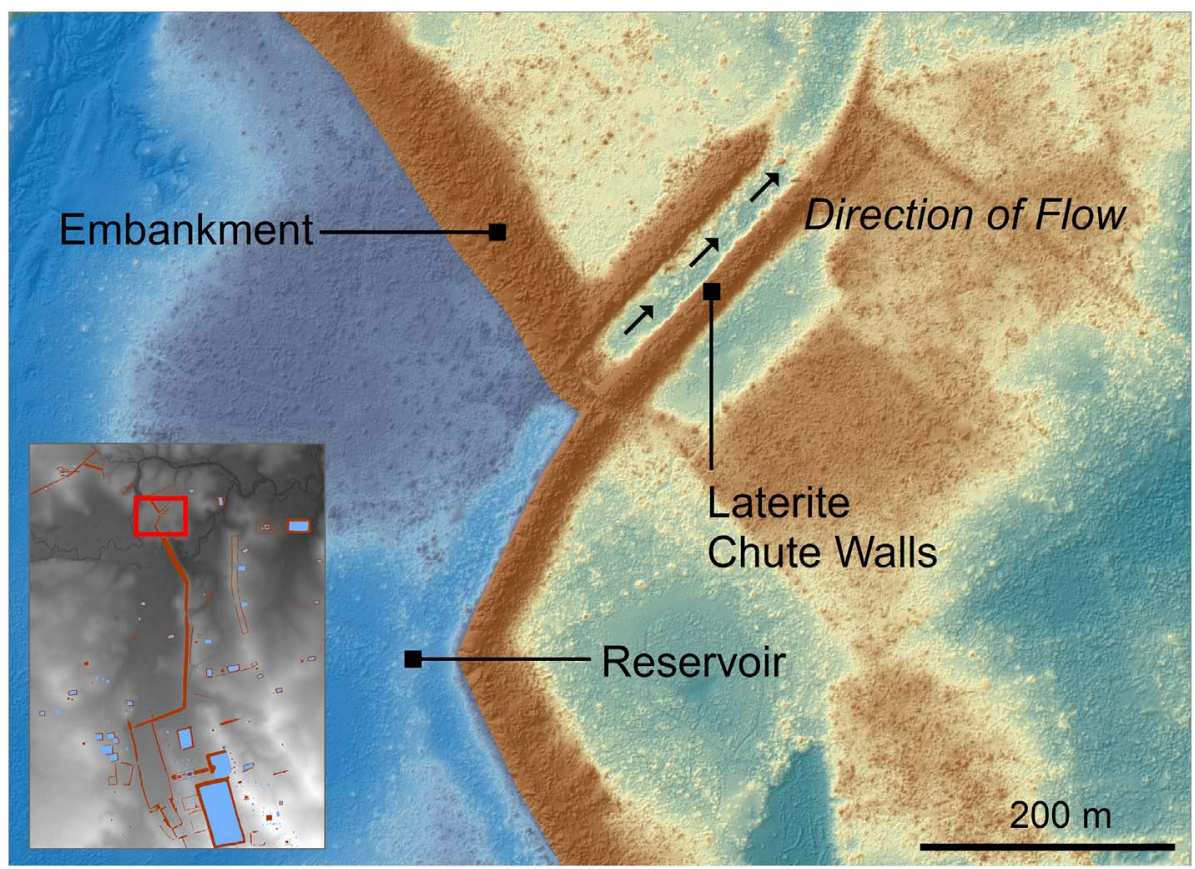

Fig. 5. Chute outlet. The laterite walls are about $4 \mathrm{~m}$ high at about $70.6 \mathrm{~m}$ ASL. See also Fig. SI 2.

1.5 to $2 \mathrm{~m} / \mathrm{s}$, plus a wave celerity of 5.5 to $7 \mathrm{~m} / \mathrm{s}$. Wave celerity was taken as $\sqrt{ }(g d)$, where $g$ is the gravitational acceleration of $9.8 \mathrm{~m} / \mathrm{s}^{2}$, and $d$ is the typical depth of the main channel, assumed to be 3 to $5 \mathrm{~m}$ when the waterways are in flood (Rouse, 1947, 142). These velocities have then been reduced by $2 \mathrm{~m} / \mathrm{s}$ to allow for friction, such as from the leaves of the overhanging trees.

The wind speed data was taken from Siem Reap-Angkor International Airport (Iowa Environmental Mesonet, 2001). We do not know how accurate these wind speeds are, however. Wind speeds are seemingly observed to roughly the nearest one mph but recorded to one decimal place. Some entries put the wind speed at as much as $1 \mathrm{~km} / \mathrm{s}$, plainly impossible. Furthermore, the records only cover between one third and two-thirds of any one year. Nevertheless, as these are the only records available for this part of Cambodia, we were constrained to rely on them, removing the highly unlikely readings, and recognizing that our conclusions must be provisional.

Wave heights were estimated using the tables in Chapter 3 of the Shore Protection Manual (Coastal Engineering Research Center, 1984). Wave runup ${ }^{9}$ was estimated using Chapter 7 of the same manual. We estimated from the lidar data that the slope of the embankment was around 0.2 , and took the elevation of the ground just upstream of the embankment to be $68.5 \mathrm{~m}$ ASL. Allowing for erosion and accretion over the last 1100 years, we think that the elevation was possibly more like $68 \mathrm{~m}$ ASL, but we have assumed the higher elevation, to be conservative.

\subsection{The embankment}

This section sets out details of the embankment, highlighting aspects that may help explain how it overtopped and failed. Most of the embankment structure was built of earth, with a trapezoidal profile. The lidar imagery for Koh Ker (Evans, 2010-2011, 95) shows that the thickness of the base varied from 15 to $150 \mathrm{~m}$. We can be quite confident that the crest was meant to be no lower than $70.6 \mathrm{~m}$, since the

\footnotetext{
${ }^{9}$ When the waves break against an embankment, they can "run up" the slope to a level higher than the crest of the wave. The wave height is measured as the vertical distance from crest to trough. The wave runup is measured from still water level (SWL). So, the crest of a $0.2 \mathrm{~m}$ wave is $0.1 \mathrm{~m}$ above SWL, but the wave runup in this example reaches $0.19 \mathrm{~m}$ above SWL, $0.09 \mathrm{~m}$ higher than the crest of the wave.
}

lidar ground returns provide accurate measurements of the elevation of the intact portions of the laterite walls of the chute (Fig. 5) and of the wing walls of the spillway (Fig. 6) at about $70.6 \mathrm{~m}$ ASL. It would have made little sense to have the embankment lower than this since the walls of both outlets would have been above the maximum height reached by the reservoir waters. Nevertheless, we shall see that the crest was indeed below this level in places.

It was not clear how the route for the embankment was determined. It is straight in parts and curved in others. Two long, straight sections, which are parallel to each other, meet at the spillway, but do not line up. Often where the embankment traverses low ground, there is high ground about $100 \mathrm{~m}$ away, and building it there would have reduced the effort of construction substantially. About a kilometer to the east, there is an even longer and higher ridge. At its northern end, the original Rongea floodplain narrows, and building a water-retention structure at this pass with a spillway elsewhere would have entailed even less effort and rendered the spillway more resistant to high-velocity flows, particularly if the spillway site had underlying sandstone near the surface (Fig. 3).

The north-western section of the embankment appears to be unfinished (Fig. 7). Again, allowing for erosion, we suggest that it may have run eastwards from the Wat Phu Road at an elevation of about $71.5 \mathrm{~m}$ ASL for about $400 \mathrm{~m}$ until it met a lower embankment with crest seemingly at $70.6 \mathrm{~m} \mathrm{ASL}{ }^{10}$ At one location, this lower embankment appears to have been eroded and then repaired, then eroded again (Sections 2.3 and 2.6), suggesting that the embankment was overtopped twice.

One unlikely scenario is that because the surveying techniques were not accurate over the $7 \mathrm{~km}$ of embankment, it could have been built too low in places to contain the waters of a full reservoir. Perhaps, as part of the construction process, the engineers noted where overtopping started to occur at high water levels, so that eroded sections could be filled in more accurately. Nevertheless, we have the fact that the levels of the tops of the walls of the spillway and the chute are within $0.1 \mathrm{~m}$ of each other, yet these two structures are nearly $2 \mathrm{~km}$ apart. They must have been leveled using a water surveying technique, and if so, it might

\footnotetext{
${ }^{10}$ Since the elevation of its northern continuation varies with the surface of the ground, this lower embankment may have been adapted from an access road constructed with resources more limited than once Koh Ker became the political centre.
} 


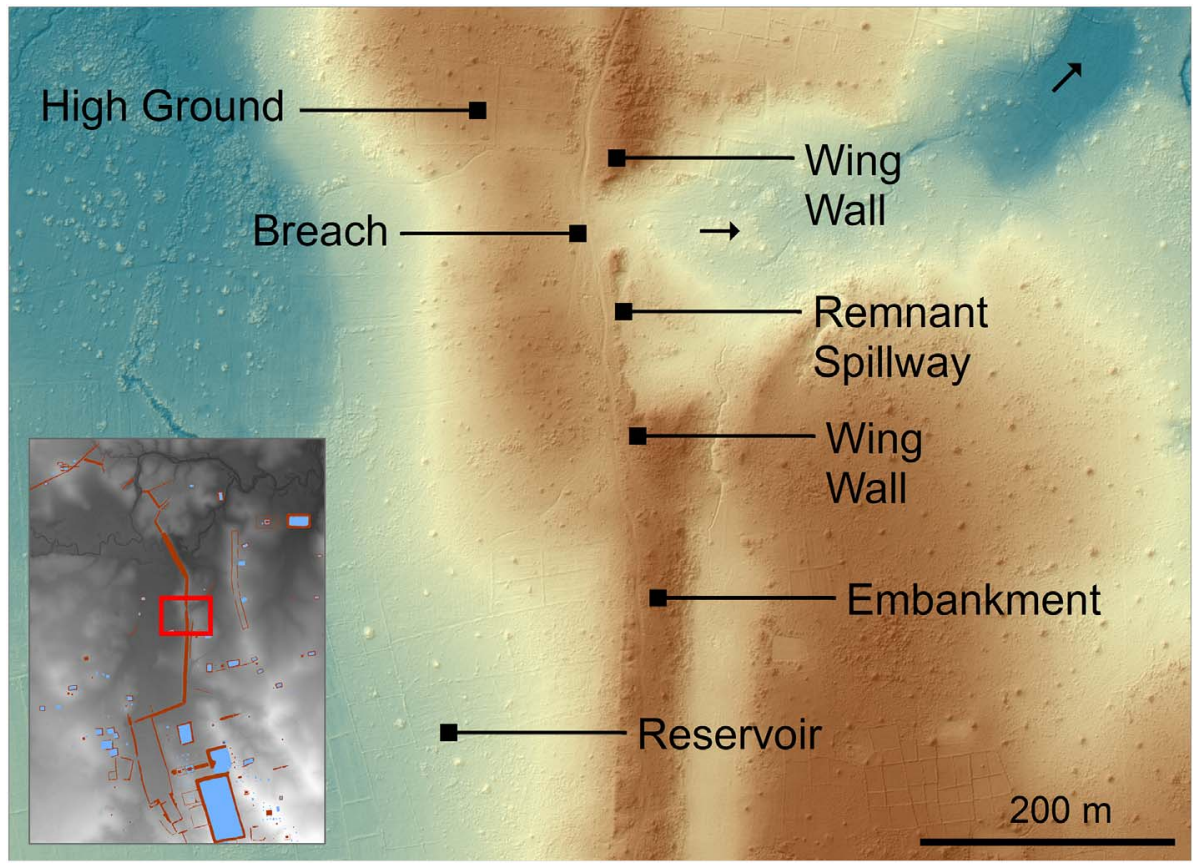

Fig. 6. Spillway with high ground upstream, and washed out at northern end. The tops of the wing walls are at about 70.6 m ASL. See also Figs. SI 3 and SI 4.

be expected that this was used for the rest of the embankment. It is possible that the tops of the spillway and chute were raised after the embankment was overtopped the first time. However, to date we have not found any indications, such as a horizontal break between two rows of blocks, that the walls were built in two stages.

Another possibility is that the crest of the embankment wore down or eroded in places after the embankment was first constructed. If this was the case, the first overtopping may have been some years after the embankment was built.

It may be too that this first overtopping may have prompted Jayavarman IV to start raising the level of the embankment. Indeed, the embankment to the northwest of the chute appears to have been at $72.5 \mathrm{~m}$ ASL for about $400 \mathrm{~m}$. The implication is that Jayavarman was in the process of raising the whole embankment, but this was not completed in time. Thus, the failure would likely have been within a couple of years of the first overtopping.

\subsection{Overtopping and repair of the embankment}

This section outlines evidence for the embankment being overtopped twice. Much of the embankment is still higher than $70.6 \mathrm{~m}$, and some is above $71.5 \mathrm{~m}$ ASL today (Fig. 8), so it is reasonable to suppose most of it was initially higher than now and has since eroded.

The erosion marks in Fig. 7 are too high to have been formed by natural runoff from the landscape, and are consistent with the ground being washed away by water from the reservoir. Points 1 and 2 show erosion less than at Points 3 and 4. But if we look more closely at Point

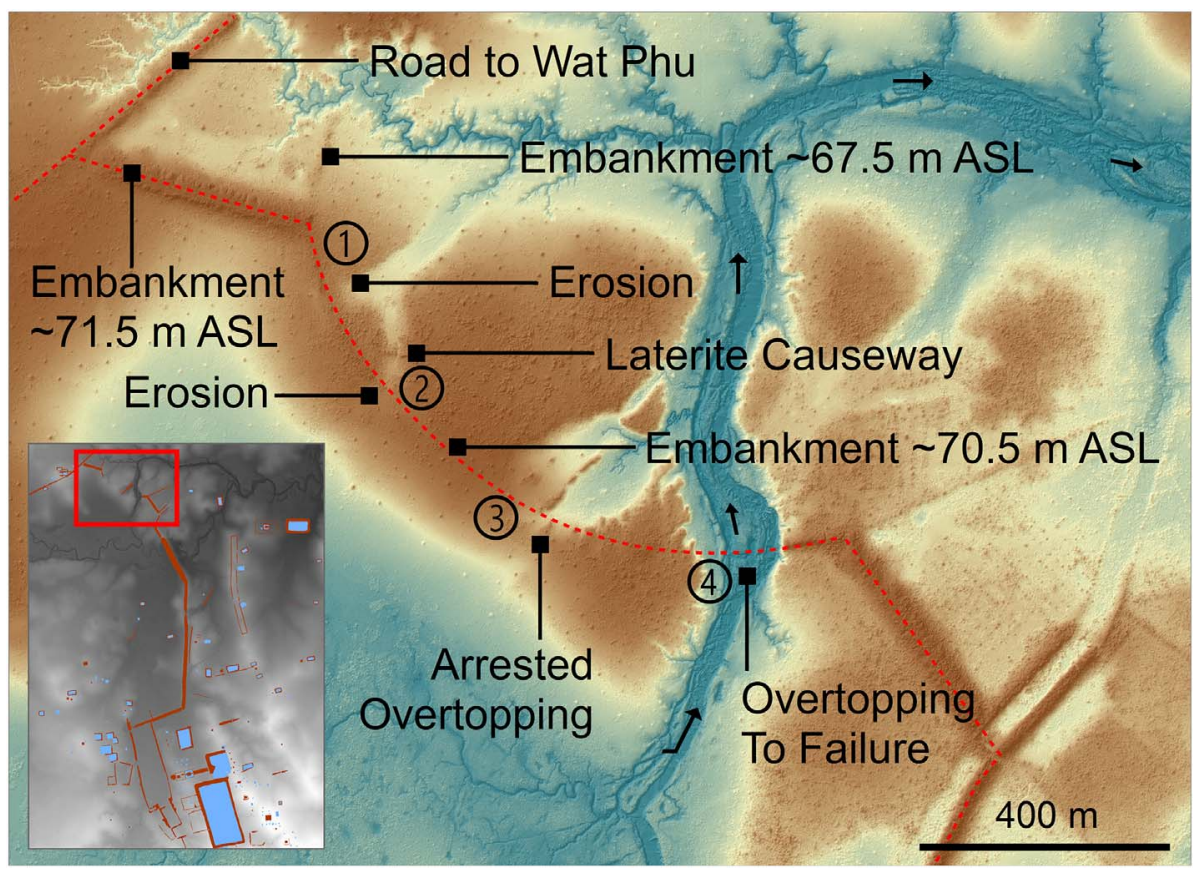

Fig. 7. Northwestern section of embankment. The high embankment meets a possibly older embankment, which appears to have been eroded by water from the reservoir when it overtopped the first time. The embankment seems to have been replaced with a new one (Points 1 and 2). Both sections seem to have eroded a second time, possibly when there was also overtopping further east (Points 3 and 4), with the river forming at Point 4. 


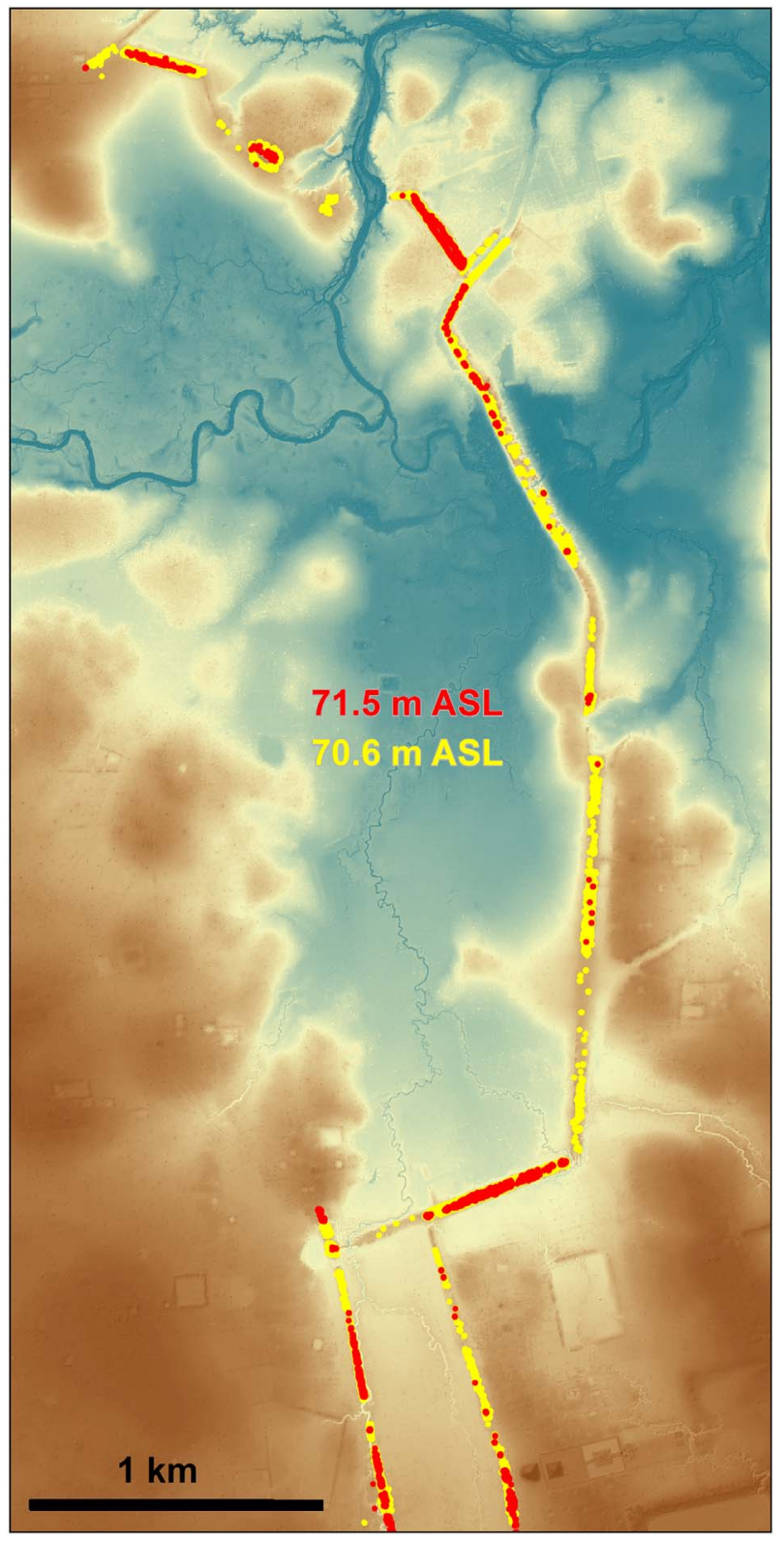

Fig. 8. Embankment showing where the crest is at or above $70.6 \mathrm{~m}$ ASL (yellow) and $71.5 \mathrm{~m}$ ASL (red), respectively.

1 in Fig. 9, we see that the natural ground appears to have been eroded down to about $68 \mathrm{~m}$ ASL, then filled in with a $2.5 \mathrm{~m}$-high embankment - if our assumption that the level of the crest was built up to around $70.6 \mathrm{~m}$ ASL the second time is correct. ${ }^{11}$ Then this embankment was eroded again, in places, down to about $69 \mathrm{~m}$ ASL. At Point 2, the erosion apparently lowered the ground and formed a shallow gully on the downstream side. Two laterite pavements have been constructed across this gully, presumably after the first overtopping. These are not horizontal, suggesting that they have settled since, perhaps because their sandy-clay foundations became super-saturated and lost strength. Erosion Points 3 and 4 are shown in more detail in Fig. 10. The shape of the ground at Point 3 is consistent with the patterns created in soil when eroded by water overtopping about $200 \mathrm{~m}$ of a level embankment. At Point 4, the erosion was so great that a new river channel formed.

\footnotetext{
${ }^{11}$ There are still a few sections of this part of the embankment that reach this height.
}

\subsection{Wave protection}

This section provides details of how the embankment was protected against erosion of the upstream face by wave action, one of the hazards to the safety of water-retention structures. The size of a wave will depend on the velocity of the wind and the length of the fetch. ${ }^{12}$ Waves generated in deep water embody greater energy and pose a greater danger to an embankment than those formed where the water is shallow. ${ }^{13}$ There are laterite blocks at or near the top water level of the reservoir (Shimoda \& Sato, 2009, 37) along much of the upstream face of the embankment. Where the embankment starts to cross the original floodplain, the reservoir would have been as much as $8 \mathrm{~m}$ deep, and laterite blocks were placed carefully in stepped layers over the full upstream face. Along the shallow sections of the embankment, the laterite was placed on the upstream face mostly as loose rubble blocks or occasionally as a rough pavement. Sometimes where the water would have been very shallow, there was no laterite at all. We suggest that the laterite was emplaced to protect the upstream face of the embankment from waves.

The reservoir would have remained close to full through the dry season. ${ }^{14}$ The construction workers could not have placed the stepped laterite blocks on the submerged parts of the upstream face of the bank, so these must have been placed there beforehand, during construction. However, along sections where the embankment was on high ground, it is possible that some of the laterite protection was placed after construction, during or after the first one or two rainy seasons, when the size of the waves breaking against the embankment could be observed.

We need to offer one qualification to this assessment, however. It is sometimes difficult to distinguish between laterite blocks that have been placed on a surface as rough protection, and laterite that forms naturally below the ground and is exposed when the overlying soil erodes. We have found laterite that has formed within the main embankment, which is only about 1200 years old. However, we feel that we have differentiated between natural and placed laterite in the main correctly. In most places laterite rubble can be found on the upstream face of the embankment, but not on the downstream face as well, which we should expect if the laterite has been produced there naturally. Only at Point 1, the location that seems to have been eroded and repaired, does the exposed laterite appear to be natural (Fig. 9).

\subsection{The outlets}

This section outlines our investigation of capacities and resistance to failure of the two outlets from the reservoir, the chute (Fig. 5), and the spillway (Fig. 6). We have followed up Evans' initial investigations with field surveys from 2013 to 2016, together with excavations in 2015. Clearing of the vegetation on the spillway and at the chute showed the remains of structures with ogee-form profiles (Fig. 11), a hydraulically efficient shape in standard use for the design of many modern spillways (Chanson, 2004, 396). Bam Penh Reach north of Angkor (Lustig, 2012, 210), probably built under Yaśovarman I (889-910 CE), is the only other known example of this type of profile in the Angkorian realm (Fig. 12), although it is less well developed.

\subsubsection{The spillway}

Much of the spillway has been washed away and deposited about 10 to $20 \mathrm{~m}$ downstream. Many of the blocks were removed in layers, highlighting both the lack of keying between the blocks, as was practiced at Bam Penh Reach (Fig. 13), and/or their being too small to resist

\footnotetext{
12 The fetch is the distance that the wind blows over the water, building the wave up more and more as it approaches the shore.

13 This is because a shallow bottom creates friction and induces waves to break offshore (Coastal Engineering Research Center, 1984, 2-129).

${ }^{14}$ From the calculations for evapotranspiration described in Section 2.1, we found that the reservoir level would likely drop less than a meter.
} 


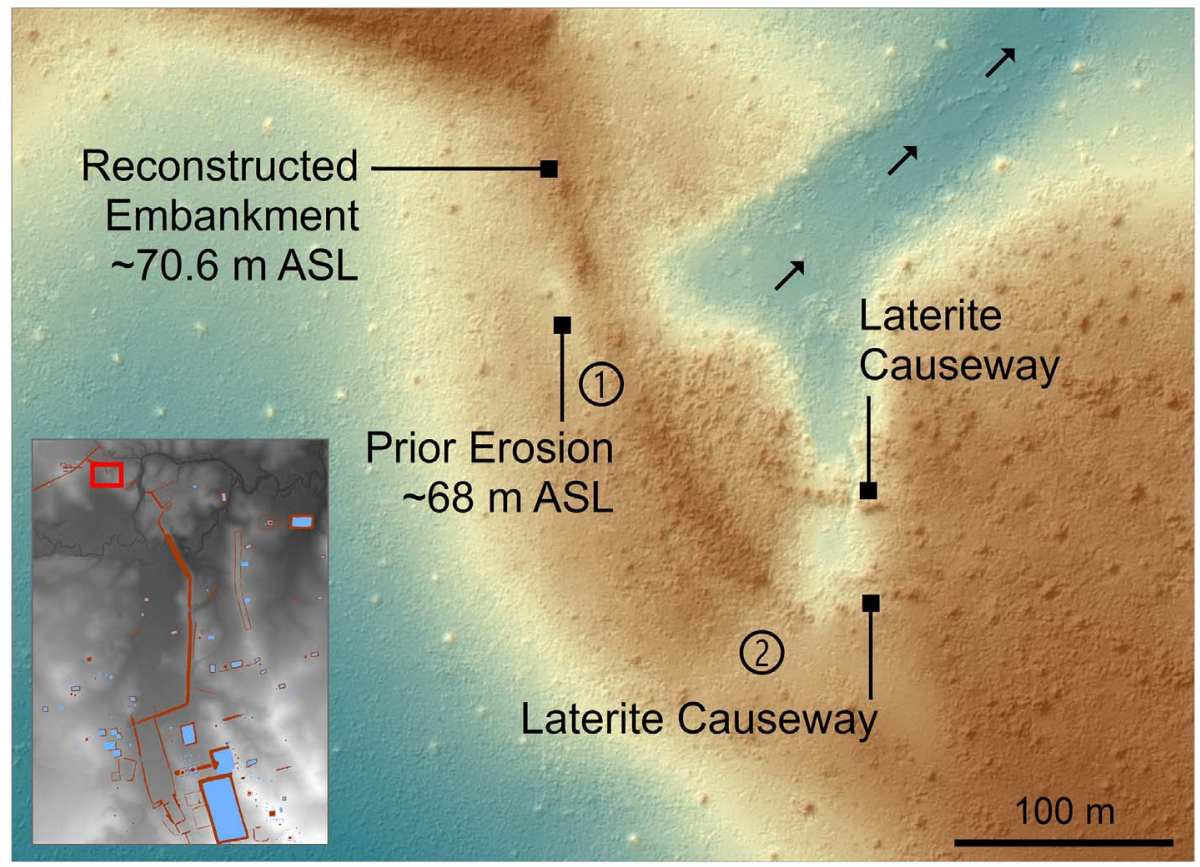

Fig. 9. Overtopping Points 1 and 2 showing indications of prior erosion having been covered over with reconstructed embankment, estimated to be at $70.6 \mathrm{~m}$ ASL. The lighter the colour, the higher the ground. The low ground at Point 1 at elevation $\sim 68 \mathrm{~m}$ ASL appears to be the remnants of a channel created by erosion during the first overtopping, which was then filled in before being overtopped and eroded again. The laterite causeways at Point 2 would have been built after the first overtopping, which formed the channel there. the high velocities of water flowing over the spillway. Laterite blocks have also been located as far as $500 \mathrm{~m}$ downstream, supporting the idea that the failure of the spillway was catastrophic. This major breach can be seen clearly (Figs. 6 and SI 3).

As illustrated in Fig. 11, the water flowing over a spillway accelerates as it passes over the crest, and then accelerates further as it runs down to the toe of the embankment. Near the bottom, the water plunges into turbulent water, and could undermine the foundations supporting the toe. The flow of water over the spillway seems to have undermined the laterite blocks where they rested on clayey sand, but not so much where they had been placed on sandstone, as this part of the embankment is still largely intact. Today, one would protect the toe by installing a mechanism for dissipating the high energy to protect against erosion, but this was not done here. Where the toe was undermined, a 50-m wide section of the spillway is missing. (See also Fig.
SI 3.)

A deficiency in design that contributed to the failure of the embankment was that the spillway was founded on the low side of a sloping sandstone rock shelf. We judge from the lidar, together with surveys on site, that the elevation of the crest may have been originally at about $69.6 \mathrm{~m}$ ASL. However, there is a ridge of sandstone whose crest ranges from $68.9 \mathrm{~m}$ to $69.7 \mathrm{~m}$ ASL just upstream (to the west in Fig. 6). It is impractical to construct a spillway at a level that is at much the same level as a ridge just upstream. With the adopted layout, this high ground upstream would have impeded the flow of water from the reservoir to the spillway, so the structure's capacity for discharging excess flows was less than optimal.

The crest of the natural rock to the west is about $400 \mathrm{~m}$ long, so building the spillway there would have entailed much less effort than was expended with the adopted layout, and would have provided much

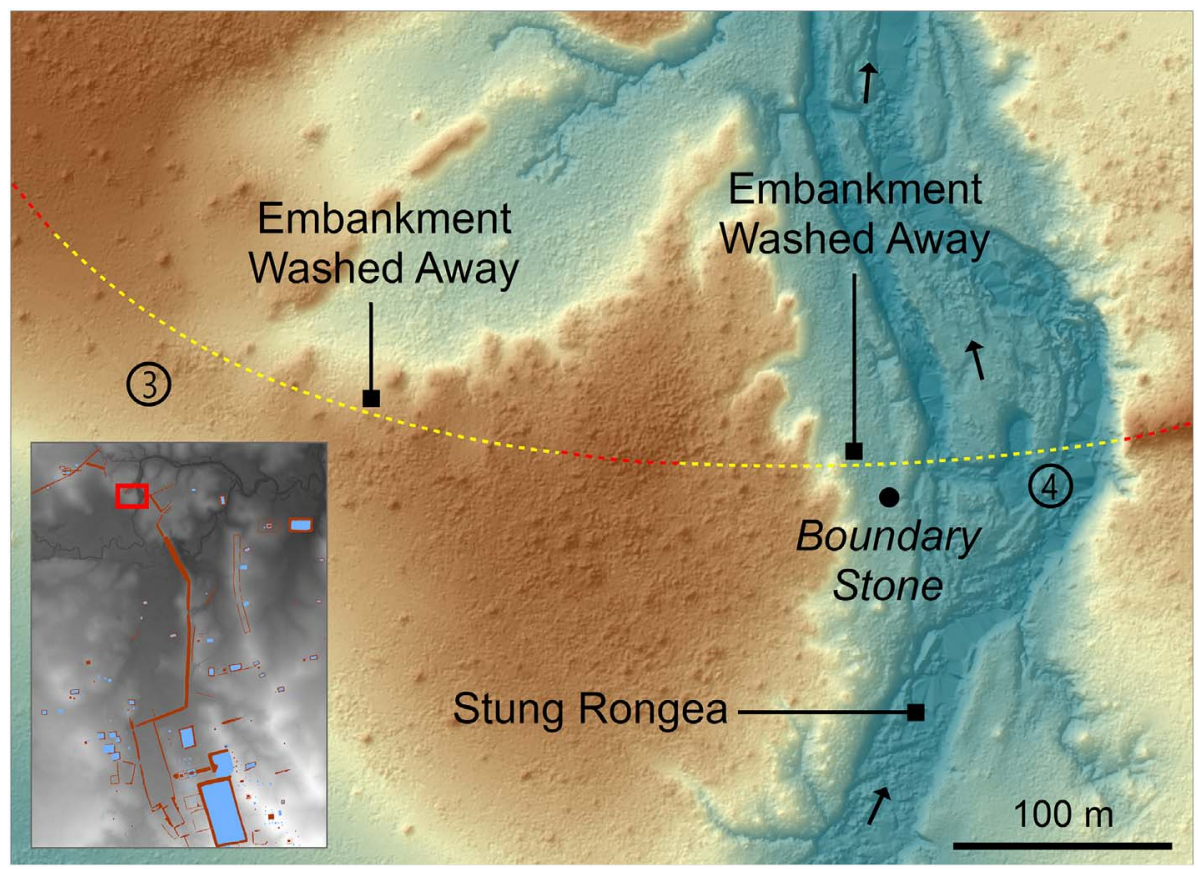

Fig. 10. Overtopping Points 3 and 4. Boundary stone in line with embankment on left bank of the Stung Rongea indicates that the embankment initially continued westwards along high ground. The yellow dotted line shows an approximate line of embankment, before being washed away. 


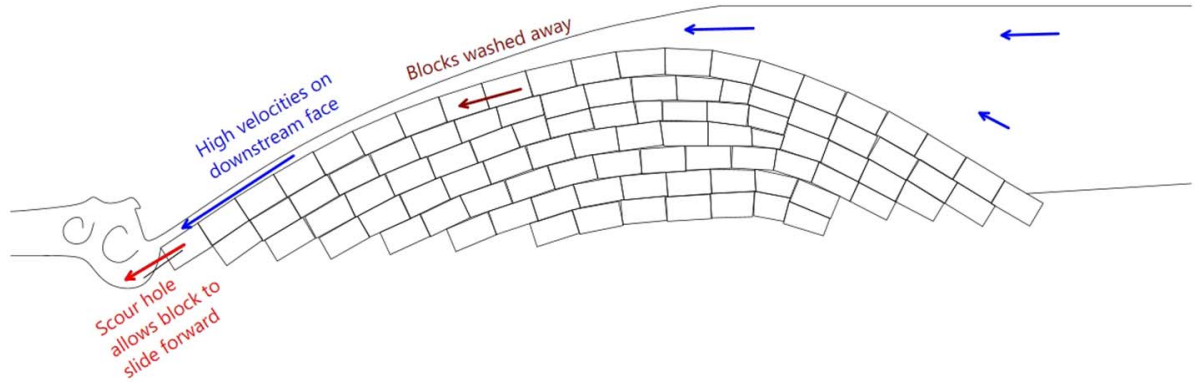

Fig. 11. Schematic diagram of laterite spillway showing zone of scour by water flowing over the ogee-form spillway.

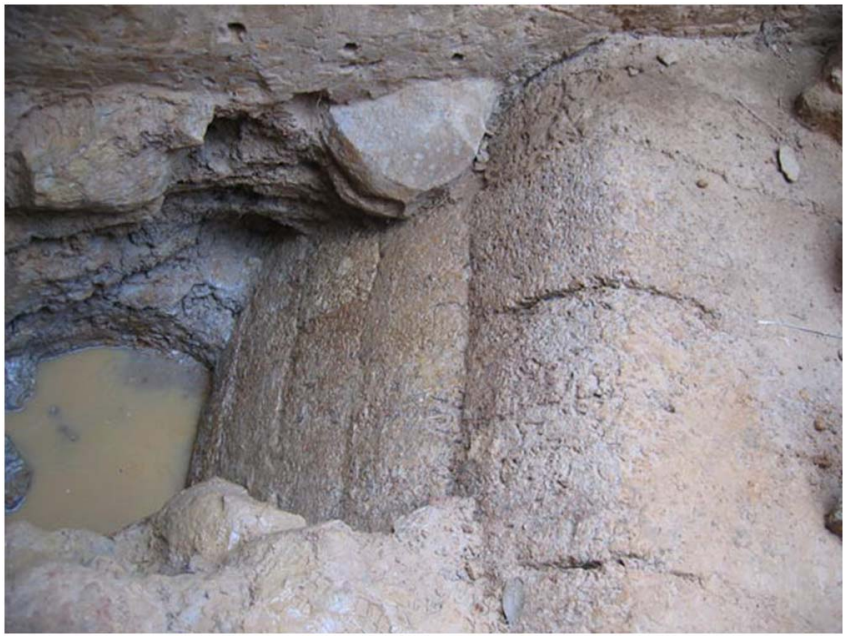

Fig. 12. Spillway at Bam Penh Reach, north of Angkor, showing ogee form at top layer of laterite. (Photo by Andrew Wilson.)

greater capacity and better foundations for controlling excess flows. We judge that the spillway could have been on the point of washing away when the reservoir reached a level of $70 \mathrm{~m}$ ASL, if not sooner. A level of $70 \mathrm{~m}$ ASL would mean that the depth of water at the crest of the spillway would have been about $0.27 \mathrm{~m}$ and the velocity there would have been about $1.6 \mathrm{~m} / \mathrm{s}$. However, the velocity at the toe of the spillway would have been higher, of the order of $4 \mathrm{~m} / \mathrm{s}$ with a depth of flow of about $0.1 \mathrm{~m}$, depending on the degree of roughness afforded by the imperfectly aligned laterite blocks. We suggest that the toe of the spillway being undermined caused failure, but that with perhaps three

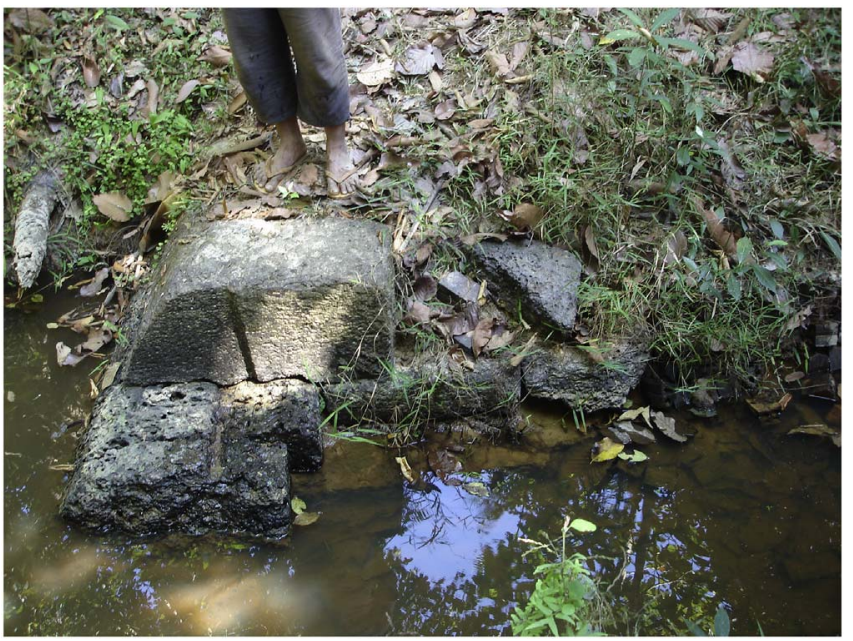

Fig. 13. Section cut through spillway at Bam Penh Reach in the 1970s, showing keying between blocks. months of wet weather before this event, there could have been protective vegetation at the toe and this would have provided some initial protection against erosion. Good grass cover, for example, might resist a velocity of $4 \mathrm{~m} / \mathrm{s}$ (Hewlett et al., 1987, Fig. 9). If the vegetation was quite dense, (it can grow quickly in this area during the rainy season), it could have provided some impedance to flow, helping the supercritical flow at the toe to become subcritical through a hydraulic jump.

Nevertheless, with these flaws in the design of the spillway, it might be expected to have required repairs and upgrading during and after each rainy season to remain functional, and if these had been effective, they would likely be discernible today. Indeed, had the main spillway been repaired to any substantial degree, its design would quite likely have been modified to increase its durability. We would expect this to be quite apparent, in the form perhaps of appreciably larger laterite blocks; keys in the blocks; a new ogee-form spillway profile with shallower slope; or some other substantial mechanism for preventing the blocks from washing away under high velocity. The fact that we have not found any evidence of repairs with appreciably altered designs suggests that the spillway lasted very few seasons, as will be discussed below.

\subsubsection{Chute}

After the site was cleared of vegetation, two linear structures were exposed, one a laterite spillway, as had been suspected, with crest level $68.5 \mathrm{~m}$ ASL, the other a laterite rectangular pavement-like structure with elevation around $69.8 \mathrm{~m}$ ASL (Fig. 14).

The chute may have failed less dramatically than the main spillway to the south. The spillway in the chute has a much gentler slope and the blocks that eroded at the toe - again there was no energy dissipator do not seem to have resulted in a rapid failure of the whole structure. Our probing did, however, find gaps in the subsurface laterite layer, and this was supported by the results of the ground penetrating radar (GPR) data from the chute, which showed that about a third of the spillway eroded severely, but that some of it remained largely intact. Detailed hydraulic modeling will be required to estimate the peak velocities of the water flowing over the reasonably complete portions of the spillway, but they do lend support to the idea that the water in the reservoir was not much higher than $70 \mathrm{~m}$ ASL when the embankment failed.

The quality of construction of the rectangular structure was poorer than that of the chute spillway, and it seems to have been built with four or five layers of laterite blocks. These appear to have been taken from the spillway after it ceased functioning. It is not a hydraulic control structure, as its level is too high to allow any appreciable flow downstream, and it is consistent with the form of a pavement. ${ }^{15}$ If this was its function, its location and orientation could have helped satisfy an objective of providing unbroken access from the Angkor-Wat Phu highway to Koh Ker. While local people of the time could have installed these blocks, the utility of such a structure to them would seem to have

\footnotetext{
${ }^{15}$ Christophe Pottier (EFEO, pers. comm. 2017) queries this, since a pavement should not require four or five layers of laterite for its construction.
} 


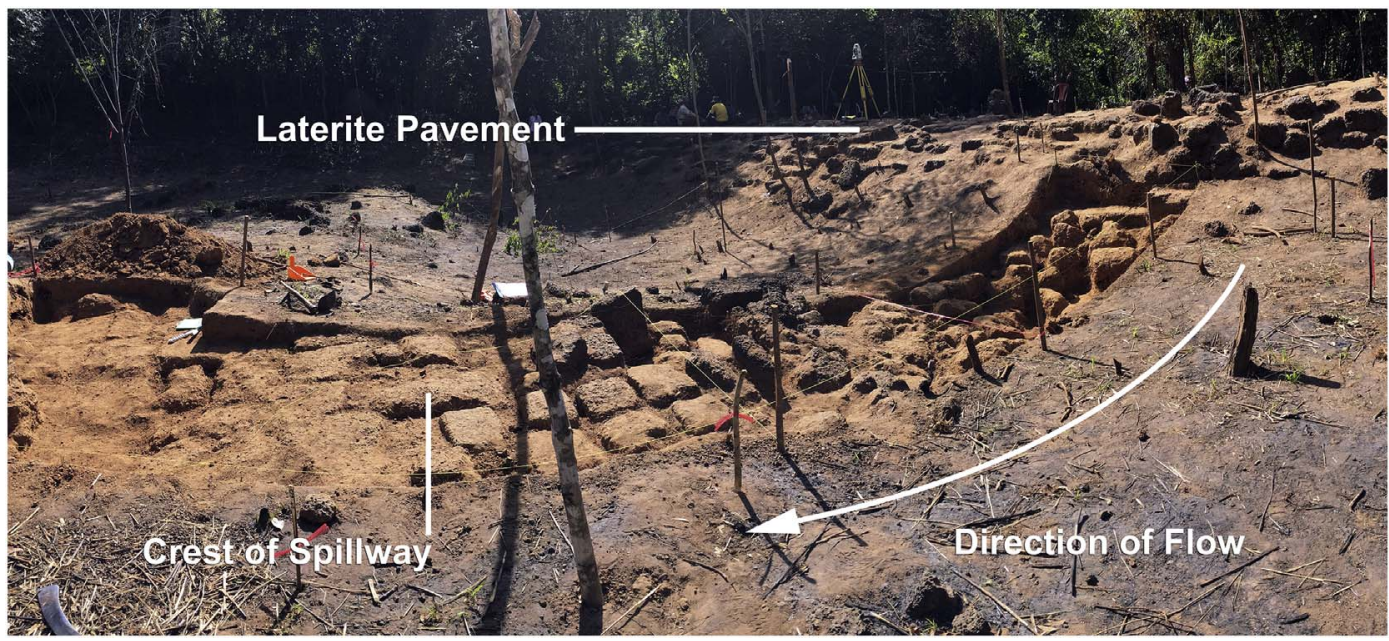

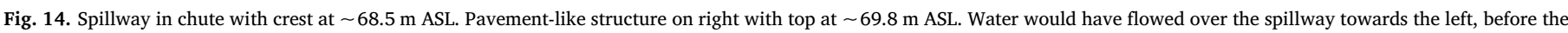
pavement was there.

been small relative to the large effort this would have entailed. We argue that it must have been built under royal authority, probably once the Stung Rongea had overtopped and eroded the northern embankment. Blocking the chute would have become acceptable when it was no longer needed for discharging water.

\subsection{The failure}

Where the Stung Rongea passes the eroded embankment (Point 4 of Fig. 10), its elevation is about $10 \mathrm{~m}$ below the crest, or about $8 \mathrm{~m}$ below the level of the natural ground. The left bank has a smooth convex surface, consistent with erosion by $8 \mathrm{~m}$ of water from the reservoir. There is no laterite on the ground, testament to the very high velocities typical of a dam break. There is only the one large and heavy sandstone boundary marker, which must have resisted the drag of the water.

We suggest that the second overtopping of the embankment was within a couple of years of the first event, since work to raise the level to $71.5 \mathrm{~m}$ ASL or higher along the length of the embankment had not yet been completed, and with the large workforce at hand, this should have taken only a few months. We think that failure was within a few hours, since the spillway must have washed out at the same time. Had it washed out earlier, the large outflow would likely have prevented the level of the reservoir from rising and overtopping the embankment. It could not have been destroyed later, since there would no longer have been any water to overtop it. We shall now examine the feasibility of the embankment overtopping twice in a couple of years.

\section{Feasibility of overtopping twice in a couple of years}

We envisaged several scenarios for overtopping the embankment twice within a short period: flows which were so great that they exceeded the capacity of the spillway and chute outlets; poor maintenance of the embankment; and waves generated on the surface of the reservoir by strong winds running up the embankment and overtopping it. We studied these scenarios using hydraulic, hydrological and wave modeling as described in Section 2.1.

\subsection{Flows down the river and through the outlets}

We will now set out the results of the hydraulic modeling. When we compared the water levels that villagers had observed along the river upstream and downstream of the embankment, and plotted them

\section{High roughness}

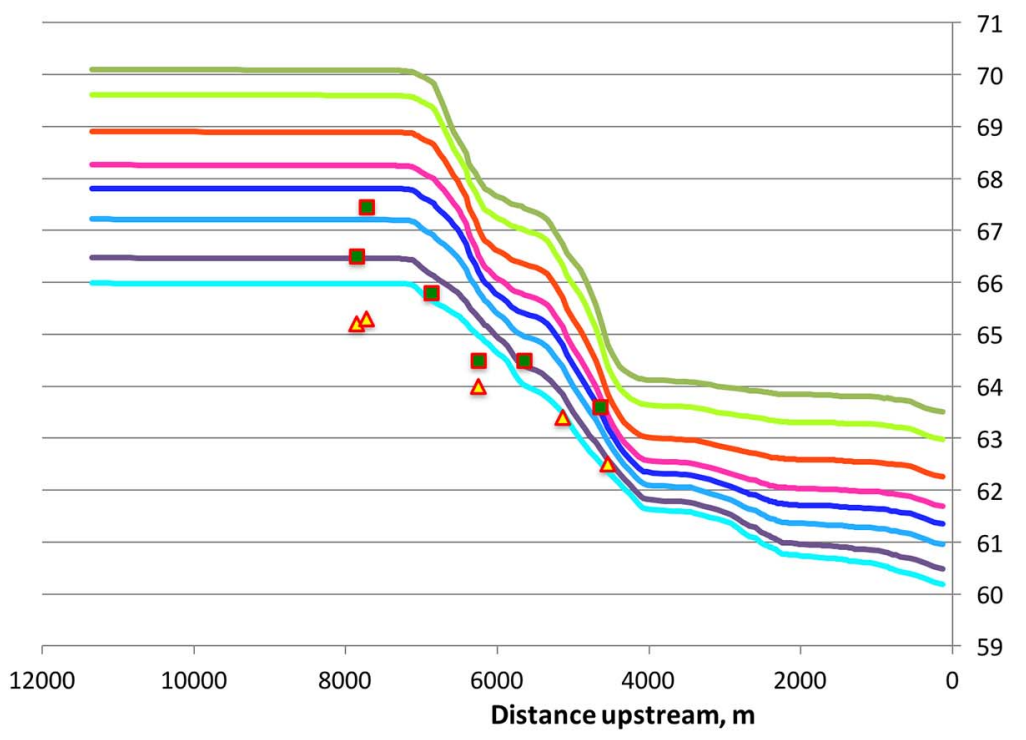

Fig. 15. HEC-RAS model results, assuming higher roughness values than normal. Points are peak water heights observed by local informants in 2013 and 2014. 


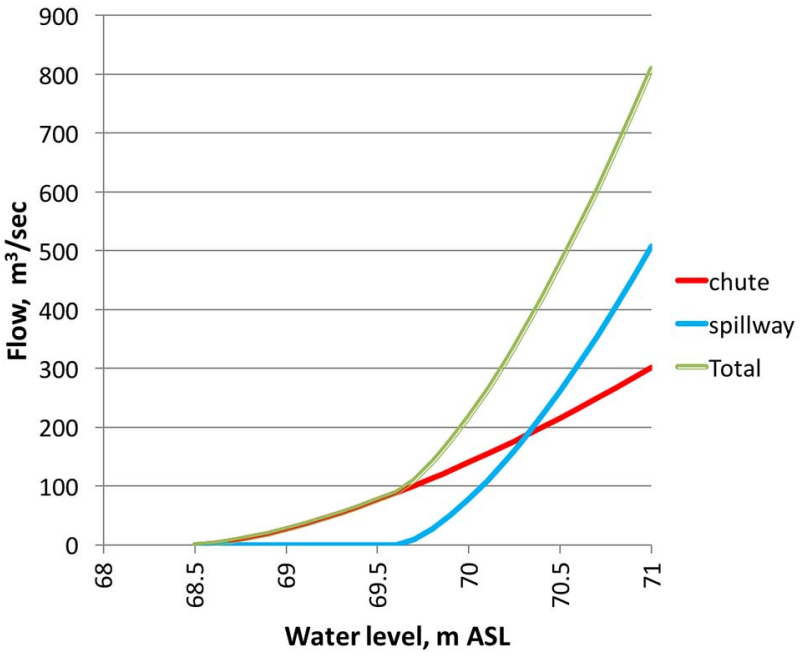

Fig. 16. Flow over both spillways increasing with water level in reservoir.

against the flows derived from the HEC-RAS hydraulic model, we estimated that the flow may normally be no less than $120-300 \mathrm{~m}^{3} / \mathrm{s}$ every year, and may exceed $300-700 \mathrm{~m}^{3} / \mathrm{s}$ on average one year in ten. The lowest estimated flows are calculated on the assumption of higher than estimated values of roughness in the river and the floodplain. The highest flows are for lower than estimated values of roughness. In what follows, we assume the high-roughness flows, so that our conclusions will be conservative (Fig. 15). The results for normal values of roughness and for roughness less than normal are in Supporting Information SI $4 .^{16}$

We next estimated the capacity of the chute and the spillway to pass river flows during the rainy season without overtopping the crest of the embankment. We calculate that the main spillway would have started flowing when the flow through the chute exceeded $90 \mathrm{~m}^{3} / \mathrm{s}$, which could have been most years, since, according to the results of our preliminary hydrological modeling discussed below, the annual maximum flow would rarely have been less than $100 \mathrm{~m}^{3} / \mathrm{s}$. We determined that the capacity of the chute and the spillway combined would have been about $220 \mathrm{~m}^{3} / \mathrm{s}$ when the elevation of the water level in the reservoir was $70 \mathrm{~m} \mathrm{ASL}$, and perhaps $540 \mathrm{~m}^{3} / \mathrm{s}$ if the elevation of the water level in the reservoir reached $70.6 \mathrm{~m}$ ASL (Fig. 16). The capacity of the chute and the spillway combined would have been exceeded when the inflow was $>540 \mathrm{~m}^{3} / \mathrm{s}$. One implication from this is that with water flowing over the chute spillway throughout the rainy season, and over the main spillway probably at least during the wettest months, it may not have been possible to undertake small repairs to these structures until the following dry season.

All this points to parts of the northwestern section of the embankment, discussed in Sections 2.2 and 2.3, having been no higher than about $70 \mathrm{~m}$ ASL at the time of the first overtopping. As outlined in Section 2.5.1 above, we estimate that had the reservoir reached a higher level, the spillway would have washed out, allowing a much greater outflow, thereby preventing a second overtopping.

If the spillway had been repaired after washing out, it is difficult to envisage that the new crest would have been as high as before. The sophisticated form of the spillway points strongly to a good understanding of its purpose and function, and rebuilding it with a lower crest should have been an option readily apparent to the designer of the

\footnotetext{
${ }^{16}$ We have since installed metric gauges and simple peak water level recorders on the upstream and downstream sides of the embankment and along the river about $2 \mathrm{~km}$ downstream from the embankment. We obtained some preliminary river heights in 2016. One useful result from 2016 was that our local informants observed that the water level stayed at the peak for about a week, while one informant who had some gauges on their property noticed one overnight peak significantly higher than the week-long peak.
}

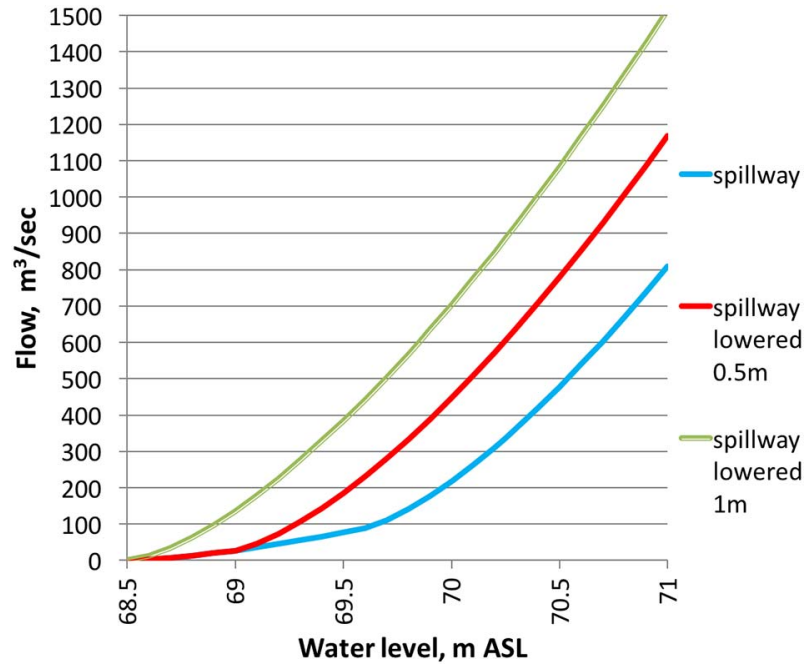

Fig. 17. Total flow over spillway and chute, and with spillway lowered.

spillway. Fig. 17 shows that the embankment could have been protected by lowering the crest of the main spillway by between half a meter and a meter. The capacity of the spillway would then have increased substantially, and the level of the reservoir during floods would have been lower as well, making the risk of overtopping negligible. Another option could have been to increase the width of the chute, thereby enlarging its capacity. It is possible that the danger of the embankment overtopping even with the crest at $70.6 \mathrm{~m}$ ASL may not have yet become apparent, because the combined capacity of the spillway and chute was found to be adequate for the flows that had been experienced till then.

Even though the states of the spillways indicate that the reservoir level was at about $70 \mathrm{~m}$ ASL when the embankment failed, we do not yet have enough information to be certain. We shall therefore investigate several scenarios for the embankment overtopping, one where the level in the reservoir is assumed to be at about $70 \mathrm{~m}$ ASL at failure, and others where the level is assumed to be around $70.6 \mathrm{~m}$ ASL.

\subsection{Scenario 1: failure during an infrequently large flood}

This scenario assumes simply that there has been a large and rare flood. The flood frequency derived by using the information from the villagers is plotted in Fig. 18 together with the results from the hydraulic modeling. The results from the hydraulic modeling were less than from the hydrological modeling for the 1-day flows, suggesting that the observed water levels may have been less than the actual peak. The maximum elevations reached in the reservoir are shown in Fig. 19 for the 3-day average modeling and Fig. 20 for the 1-day average modeling. The 3-day modeling indicated that the water level could

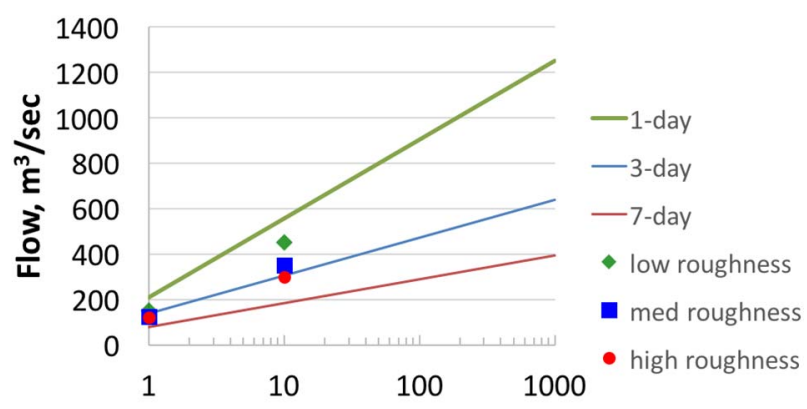

Annual recurrence interval, years

Fig. 18. Flood-frequency curve, derived from local and regional data. Markers indicate the results from the hydraulic modeling. 


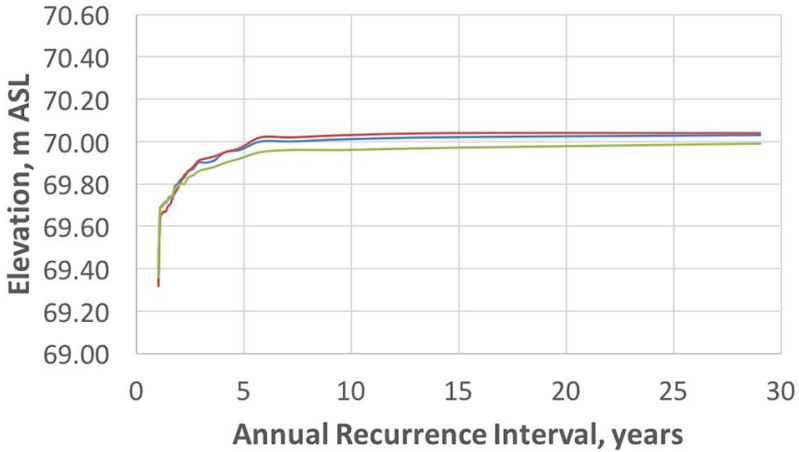

- Estimated storage —High storage —-Low storage

Fig. 19. Frequency of reservoir reaching different elevations, depending on estimated storage assuming a 3-day averaging of rainfall.

reach only $70 \mathrm{~m}$ ASL, whereas the level assumed for overtopping the embankment was $70.5 \mathrm{~m}$. The 1-day model showed that the reservoir would rise to $70 \mathrm{~m}$ one year in three, but the $70.5 \mathrm{~m}$ level might be reached once in 15 years on average. However, this scenario for overtopping was judged not to be feasible, since the time taken to reach peak water level in the reservoir was anything from 3 to $60 \mathrm{~h}$, and if it is agreed that the spillway and the embankment failed together, these times would be too long. This scenario, therefore, does not appear feasible.

\subsection{Scenario 2: poor maintenance}

Another possibility is that the embankment was not maintained adequately after it was rebuilt. We know that at Point 1 , the embankment was reconstructed and raised by about $2^{1 / 2} \mathrm{~m}$ after it was overtopped the first time. If there had not been much consolidation of the soil while it was placed, as we have observed for other medieval structures in Southeast Asia, the soil would have settled appreciably. Consolidation of soil can be of the order of $40 \%$ in the first month after loose fill has been placed (Washington State Department of Transport, 2013, 9-A-7). Had the embankment settled by only half a meter, this would have represented a consolidation of only $20 \%$, so it is quite feasible for the crest to settle from a level of $70.6 \mathrm{~m}$ ASL to a level of $70 \mathrm{~m}$. This could be why the second overtopping at Point 1 was in much the same location as where the embankment was first eroded and then reconstructed (Fig. 9), since the consolidation there would have been greatest. It is quite possible that the crest of the embankment was not maintained to its designated level with sufficient diligence - assumed here to be no $<70.6 \mathrm{~m}-$ although if the engineers were experienced in maintenance of the many embankments in the floodplain at Angkor,

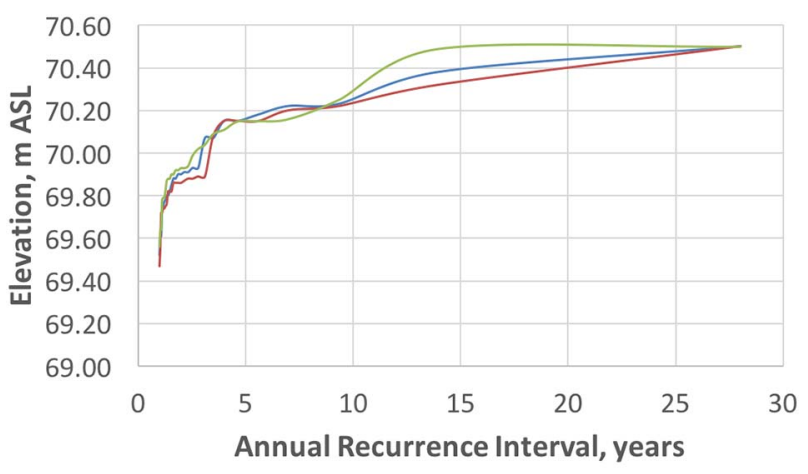

-Estimated storage —High storage - Low storage

Fig. 20. Frequency of reservoir reaching different elevations, depending on estimated storage assuming a 1-day averaging of rainfall. this should have been a hazard well appreciated by them.

This scenario is therefore feasible, particularly if the engineers were not experienced from work at Angkor.

\subsection{Scenario 3: overtopping by very large flows}

Several new scenarios were explored after the site gaugings for the 2016 rainy season brought to light that the peak flow might last for less than half a day and be significantly higher than what locals had reported (Section 3.1). It is understandable if such peak water levels may not be noticed often, since people tend to be under shelter during heavy downpours. To understand this better, we examined the pluviometer readings for Prasat Suor Prat in Angkor Park at Siem Reap, as recorded by the Japanese Government Team for Safeguarding Angkor (JSA) for the period 1997 to 2000 (JSA, 2000). The hourly rainfall for 1997 is shown in Fig. 21 as an example. The data showed that most of the peak monsoon rainfalls last less than an hour, which accords with advice that tropical thunderstorms typically last 20 to $40 \mathrm{~min}$ (Alain Protat, Australian Bureau of Meteorology, pers. comm. 2017).

Using the discharge relationships for the outlets and the storage relationships for the reservoir, we modeled the flows in and out to see what inflows could cause the water level to rise to overtop the embankment or come close to it within a couple of hours. We chose this short period, since we judged that any period longer than $2 \mathrm{~h}$ would have resulted in the main spillway failing too soon and letting the water out before the reservoir level could rise this much.

We first used the model to find the inflow, which could result in the reservoir level rising from $70 \mathrm{~m}$ to $70.5 \mathrm{~m}$ ASL within $2 \mathrm{~h}^{17}$ Fig. 22 shows an inflow that simulates what is usually observed during floods, namely a rapid rise and a slow decline. We found by trial and error that the maximum flow might need to reach about $2600 \mathrm{~m}^{3} / \mathrm{s}$ for an embankment with a low point at $70.5 \mathrm{~m}$ ASL to overtop. ${ }^{18}$

The subsequent erosion and failure would then have probably been very quick. We judge that a realistic scenario has the inflow rising to $2600 \mathrm{~m}^{3} / \mathrm{s}$ in about $20 \mathrm{~min}$, at which time the spillway might start to wash away and fail completely after an hour. The reservoir level would continue to rise until it overtopped the embankment after about $2 \mathrm{~h}$. After that, the outflow would increase as more of the embankment and the ground beneath washed away.

For the outflow scenario, we assumed that the chute remains largely intact, while the spillway starts to fail about $20 \mathrm{~min}$ after the water level rises above $70 \mathrm{~m}$ ASL, as discussed in Section 2.5.1. (Supporting Information SI 2 provides details of scoping calculations for the increase in discharge when the 50-m section of the spillway washes away.) Thereafter, the spillway fails continually, letting water flow out of the reservoir at an increasing rate. The embankment overtops after about $125 \mathrm{~min}$, and the discharge increases in stages as whole sections of the embankment and spillway wash away. The embankment would then continue to erode over the rest of the rainy season, and possibly for several seasons after that.

For this scenario to be feasible, the inflow to the reservoir would need to be much larger than has been observed in recent years. We will now examine the feasibility of thunderstorms producing such flows.

\subsection{Feasibility of thunderstorms producing overtopping flows}

Thunderstorms might produce flows of $2500 \mathrm{~m}^{3} / \mathrm{s}$ in two ways: by a single, very large storm (super cell) over the catchment or by a train of

\footnotetext{
17 We have taken the level as $70.5 \mathrm{~m}$ to allow for the effects of small waves and for some sections of the embankment to still be lower than the desired $70.6 \mathrm{~m}$ ASL because of poor maintenance.

${ }^{18}$ We are not saying that this was precisely how the inflow to the reservoir varied. We are simply deriving a hydrograph (an inflow scenario) that could have resulted in overtopping, in order to gain an appreciation of how great the flow from the catchment needed to be.
} 

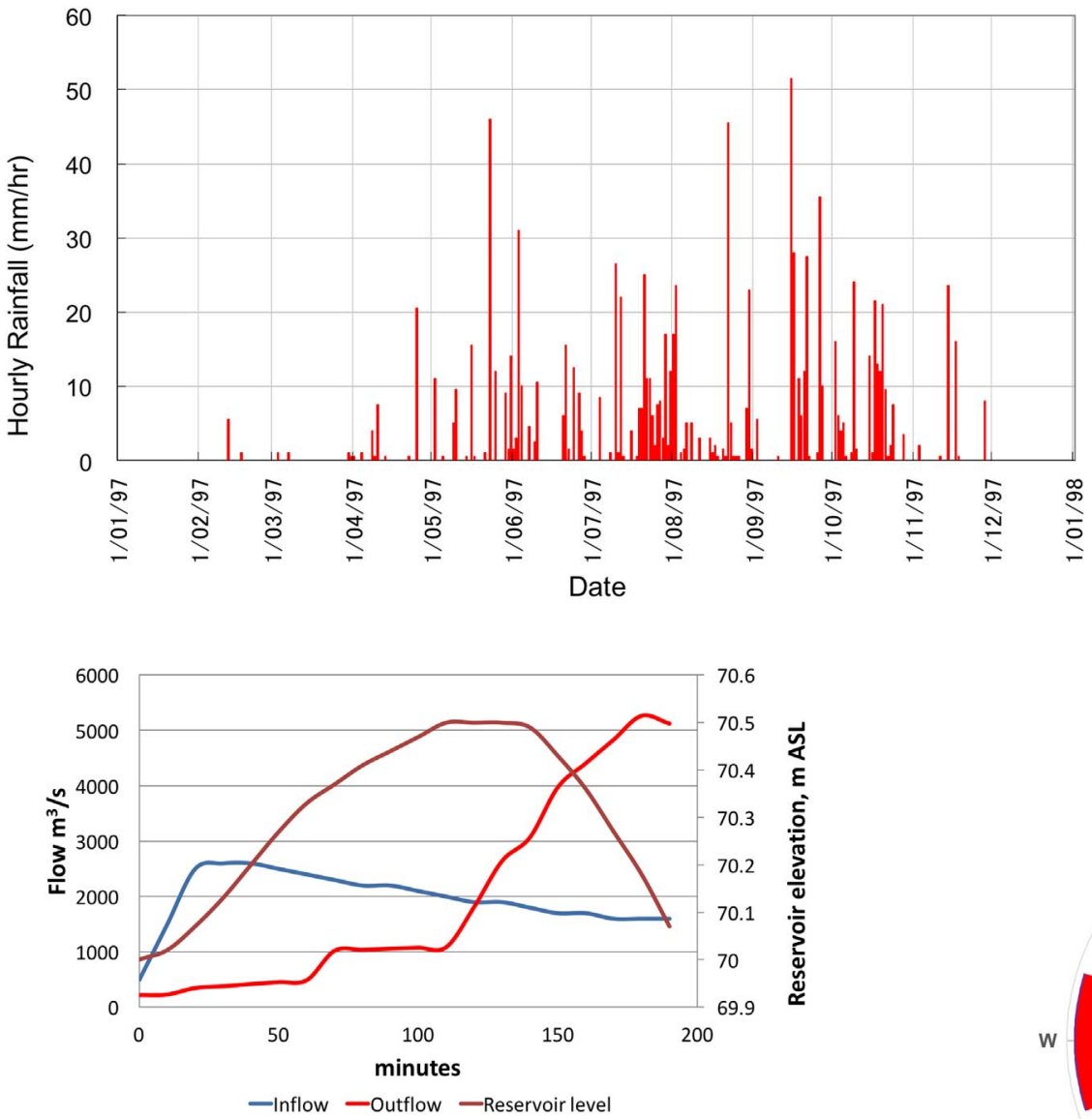

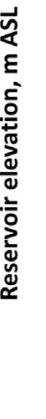

Fig. 22. Inflows, outflows and water level for overtopping by large inflows into reservoir.

storms crossing the catchment in quick succession. We suggest that while both are feasible, the second mechanism seems more likely.

If a thunderstorm formed just to the west of the reservoir during the week of peak flow in the catchment, we estimate that the flood wave from the rain could travel downstream at a speed of about 5 to $7 \mathrm{~m} / \mathrm{s}$, or 18 to $25 \mathrm{~km} / \mathrm{h}$, and reach the reservoir within half an hour. If as well, the thunderstorm cell were travelling eastwards, as will be discussed below, the flood wave would build up to a peak as it passed over the reservoir. As outlined in Supporting Information SI 3, the area of such a thunderstorm may need to be of the order of 140 to $180 \mathrm{~km}^{2}$, with precipitation of 50 to $60 \mathrm{~mm}$ within an hour, and the probability of such an event in a climate matching that of Darwin (northern Australia) might be between $3 \%$ and $5 \%$. Thus, while the frequency of large thunderstorms in Cambodia will be different from those near Darwin, having a storm just upwind of the reservoir and large enough to cause the embankment to overtop seems possible.

The second possible cause of such a large inflow to the reservoir, a series of average-sized thunderstorms in quick succession, seems more likely. Such a series is called a "mesoscale convective system" (MCS) and is an important cause of heavy rainfall and flooding in East Asia (Chen \& Chappell, 2009). ${ }^{19}$ The two predominant mechanisms for MCSs producing heavy rainfall are "training" of convective cells, where the individual convective cells follow each other in the same line, and backbuilding, where the convective cell is being continually recreated in the same location, so that the MCS is effectively stationary (Peters \& Schumacher, 2015).

It is certainly quite possible that an MCS forming near the edge of the catchment could travel in the same direction as the runoff, building

\footnotetext{
${ }^{19}$ It is also the major cause of flash flooding in the USA (Peters \& Schumacher, 2015,
} 1058).
Fig. 21. Pluviometric readings at Prasat Suor Prat for 1997. Siem Reap rainy season
$1 / 6$ to $31 / 102006$ to 2016

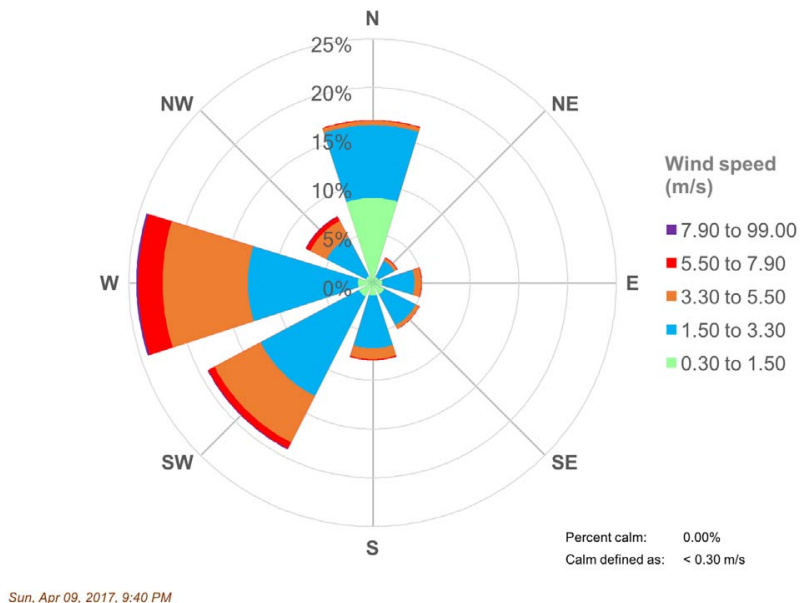

Fig. 23. Wind rose for Siem Reap Airport during the rainy season, between 1st June and 31st October. (For interpretation of the references to colour in this figure legend, the reader is referred to the web version of this article.)

up the flood as it went. We examined the wind directions for Siem Reap Airport and found that, during the rainy season (taken here as between 1st June and 31st October), the wind was coming from between the northwest and southwest (Fig. 23) for $51 \%$ of the time, over the years 2006 to 2016, the major directions of flow in the catchment.

We do not yet have good records of the frequency of MCSs in Cambodia. But we can gain a rough indication by comparing their frequency in Cambodia with those near Darwin. Ed Zipser (University of Utah, pers. comm., 2017) has compared the frequency of MCSs at the two locations using satellite data from the Tropical Rainfall Measuring Mission (TRMM) over its 17 years of data collection (Goddard Space Flight Center, 2016) (Supporting Information SI 4). He has found that while 31 MCSs with rainfall rates roughly between 50 and $200 \mathrm{~mm} / \mathrm{h}$ were recorded over the landmass near Darwin, 142 were recorded over an equivalent area centered on Cambodia - roughly five times as many. He advises that the size of thunderstorm is not as important as whether a number of them are organized in such a way as to pass over a basin in quick succession. It would appear from this that if an overtopping event resulting from a very large thunderstorm is feasible with Darwin's climate, an overtopping event in Cambodia resulting from an MCS is even more so. 


\subsection{Scenario 4: combination of Scenario 2 and Scenario 3}

We next assumed that there remained a low point with elevation at about $70.3 \mathrm{~m}$ ASL in the embankment along the northwestern sector. We found that this required an inflow of only $2000 \mathrm{~m}^{3} / \mathrm{s}$, again on the assumption that the reservoir level could rise to around $70 \mathrm{~m}$ ASL without the spillway failing. The probability of an MCS producing this inflow to the reservoir, smaller than for Scenario 3, would be greater than for Scenario 3, of course.

\subsection{Scenario 5: overtopping waves}

In this scenario, we considered that the embankment was at around $70.6 \mathrm{~m}$ ASL, but that winds generated waves in the reservoir about $0.2 \mathrm{~m}$ high, when the reservoir level was at $70.3 \mathrm{~m}$. From Figs. 7-12 of the Shore Protection Manual (Coastal Engineering Research Center, 1984), we found that a significant wave of $0.2 \mathrm{~m}$ might run up $0.19 \mathrm{~m}$ - and a third of the waves would run up further. ${ }^{20}$ Figs. $3-23$ of the same manual indicates that, with a fetch of $1.5 \mathrm{~km}$, the wind speed to produce waves with significant height of $0.2 \mathrm{~m}$ would need to be around $10 \mathrm{~m} / \mathrm{s}$. How likely is such an event?

An analysis of the wind speed data from Siem Reap-Angkor International Airport showed that in the 10 years from 2006 to early 2015 , there were few half-hour periods when the wind speed was $>$ $10 \mathrm{~m} / \mathrm{s}$, the speed needed to obtain waves this high (Table 1), and this happened only $0.3 \%$ of the period of the rainy season in the windiest year. Further, the records show few occasions when such winds lasted longer than half an hour. So, overtopping under this scenario could be quite rare.

\subsection{Summary of scenario results}

Table 2 summarises the feasibility of the scenarios we have assessed. The one that fits the available information best is Scenario 2, in essence, the result of human error, the likelihood of which might have been lessened had Jayavarman proceeded by trial and error.

\subsection{Trial and error in engineering}

While long embankments had been built on Phnom Kulen, whose rolling sandstone landscape is similar to what can be seen at Koh Ker, none that doubled as water-retaining structures were as long as $7 \mathrm{~km}$. The longest structure on Phnom Kulen that seems designed to impound water was the unfinished Thnal Mrec, $1200 \mathrm{~m}$ long (Hansen, 1968, 16). At Angkor, embankments $20 \mathrm{~km}$ long were certainly built across several watercourses (Evans et al., 2007), but these watercourses flowed across a very gently sloping alluvial fan, and their velocities were much lower, making water storage and diversion a much simpler project. At Koh Ker, the longest embankments previously built across watercourses were about $400 \mathrm{~m}$ long: one about $1 \frac{1}{2} \mathrm{~km}$ northeast of Prasat Thom, and another a little over a kilometer ENE of Prasat Neang Khmau. The watercourses they controlled had catchments of 2 and $5 \frac{1 / 2}{2 \mathrm{~km}^{2}}$ respectively, unlike that of the Rongea, which has a catchment of about $700 \mathrm{~km}^{2}$.

In building a structure unparalleled in size, Jayavarman IV appears to have failed to follow a principle fundamental to all engineering: trial and error. Even today, despite sophisticated mathematical and computer models, there comes a point in the design process where the engineer must test to see if the design works, and almost inevitably modify it to make it do so. Trial and error had already been used

\footnotetext{
${ }^{20}$ The waves generated by a strong wind would not be of uniform height. The term "significant wave height" refers to the wave height that is greater than two-thirds of the generated waves. So even if the significant wave height were just enough to overtop the embankment, one third of the waves would have overtopped the embankment easily.
}

Table 1

Number of half-hour periods wind speed at Siem Reap $>10 \mathrm{~m} / \mathrm{s}$.

\begin{tabular}{lllll}
\hline Year & $\begin{array}{l}\text { Number in } \\
\text { year }\end{array}$ & $\begin{array}{l}\text { Number in } \\
\text { rainy season }\end{array}$ & $\begin{array}{l}\text { No. in rainy } \\
\text { season } \\
\text { adjusted }\end{array}$ & $\begin{array}{l}\text { Adjusted proportion of } \\
\text { time }>10 \mathrm{~m} / \mathrm{s} \text { in rainy } \\
\text { season }\end{array}$ \\
\hline 2006 & 1 & 1 & 2 & $0.02 \%$ \\
2007 & 2 & 1 & 3 & $0.04 \%$ \\
2008 & 5 & 1 & 3 & $0.04 \%$ \\
2009 & 11 & 7 & 18 & $0.25 \%$ \\
2010 & 9 & 2 & 5 & $0.07 \%$ \\
2011 & 9 & 4 & 9 & $0.01 \%$ \\
2012 & 12 & 6 & 10 & $0.13 \%$ \\
2013 & 13 & 3 & 4 & $0.06 \%$ \\
2014 & 15 & 7 & 10 & $0.13 \%$ \\
2015 & 3 & 2 & 4 & $0.31 \%$ \\
2016 & 4 & 4 & 7 & $0.10 \%$ \\
\hline
\end{tabular}

Note: Readings giving velocities $>70 \mathrm{~m} / \mathrm{s}$ have been discounted. Adjusted proportion of time assumes similar proportion when no readings taken.

Table 2

Feasibility of scenarios.

\begin{tabular}{|c|c|}
\hline Scenario & $\begin{array}{l}\text { Qualitative assessment of likelihood of cause of } \\
\text { failure }\end{array}$ \\
\hline 1. Large, rare flood & $\begin{array}{l}\text { Not feasible, since would only cause spillway to } \\
\text { fail, not whole embankment }\end{array}$ \\
\hline 2. Poor maintenance & $\begin{array}{l}\text { Feasible, but raises question of how much } \\
\text { experienced engineers were involved. }\end{array}$ \\
\hline 3. Large storm or MCS & Significantly more likely than at Darwin. \\
\hline 4. Combination of 2 and 3 & More likely than Scenario 3. \\
\hline 5. Overtopping waves & Unlikely. \\
\hline
\end{tabular}

successfully at Angkor, as evidenced, for example, by the construction of the Indratataka at Roluos, moving on to the larger East Baray and then - after the capital's return from Koh Ker - the even larger West Baray. These were counter-intuitive aboveground water storages or baray with inflows and volumes so large that infiltration into the ground and through the sidewalls could be neglected.

Had Jayavarman built the embankment in stages over several years, for example, it is likely that the experience gained would have prompted works to increase the capacities of the outlet structures and set up systems of maintenance that helped ensure that the level of the crest would be kept above $70.6 \mathrm{~m}$ ASL, or perhaps higher.

\section{Aesthetic constraints}

This embankment was probably the only significant water management feature constructed during the time that the centre was at Koh Ker (Evans, 2010-2011, 107). While the route chosen for its construction was more costly than other alternatives, as indicated on Fig. 3, visitors to Koh Ker would have had an extensive body of water to their right, once they left the Wat Phu Road to enter the city, and then a direct line of sight to the central temple, Prasat Thom (Shimoda \& Sato, 2009, 38). Routing the road along the adjacent high ground could have meant that the access road was as much as $200 \mathrm{~m}$ away from the water, and that Prasat Thom was no longer directly ahead. Had Jayavarman chosen the even higher ridge a kilometer to the east for the access route, the water views would have been even more distant and obscured in places by high ground to the west. We suggest from this that the aesthetic effects were a significant constraint on the design.

Aesthetic considerations may also provide an explanation for the hydraulically inefficient location of the main spillway, namely downstream of high ground. We judge that it was not intended that elephants should traverse the spillway, since its crest was curved and not very wide, only about three meters. This would have made it difficult for elephants and people to cross, especially if the water were flowing at high velocity. One aesthetically pleasing option may have been to build 


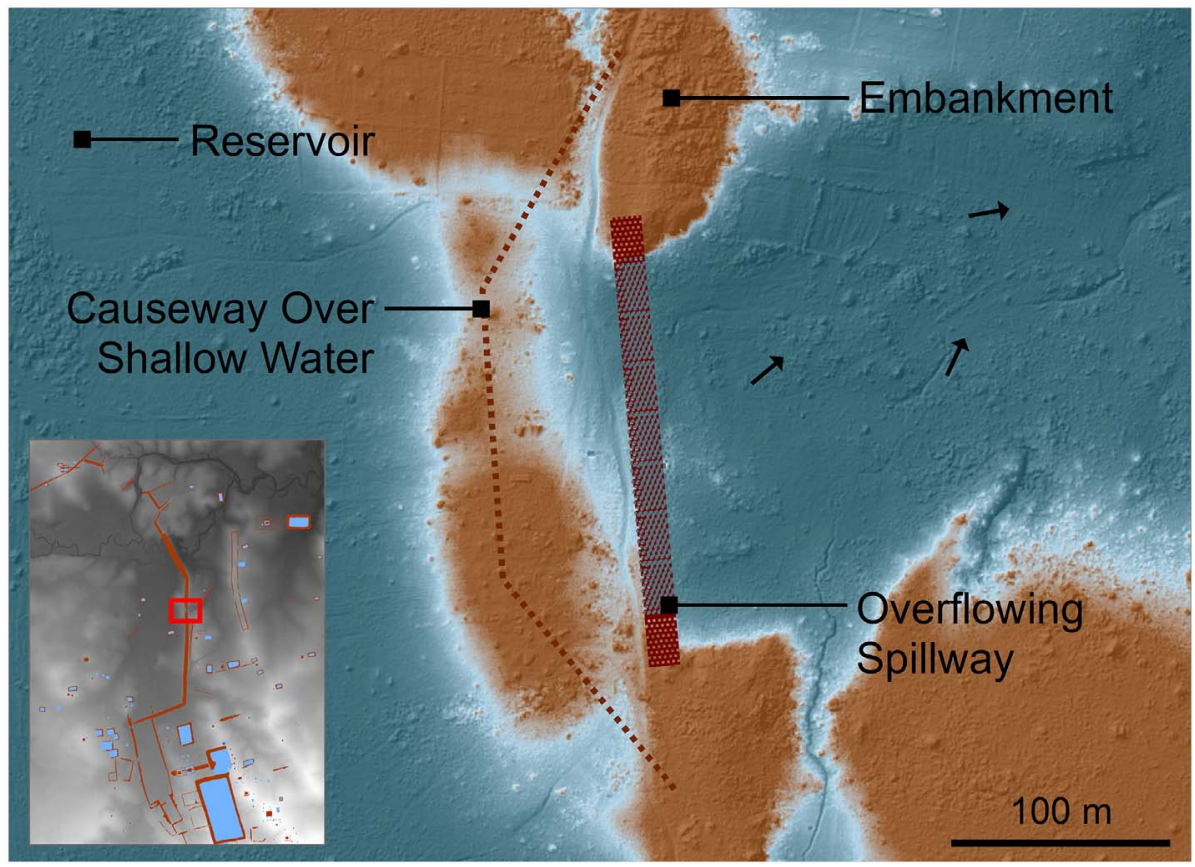

Fig. 24. Possible layout of causeway option to bypass spillway. a causeway on piers along the high ridge upstream to bypass the spillway (Fig. 24). If so, this might help explain why the main spillway was installed downstream of high ground.

If so much emphasis had been placed on the visual impacts, it would follow that the political effects of the failure of the embankment would have been profound, and could have strengthened support for the idea of returning the political center to Angkor.

\section{Discussion \& conclusion}

It is not difficult to envisage the aesthetic effect on the visitor, perhaps a pilgrim or royal entourage on the way to Wat Phu, approaching the city along the wide road along the crest of the embankment, with Prasat Thom looming ahead, and water stretching far to the west from near their feet. Few could have remained unimpressed.

The engineers at Koh Ker were set the task of constructing the largest embankment ever built across a major river during the Angkor period. The resulting reservoir significantly enhanced the volume of water available and provided an aesthetically impressive access route to the city. However, in building such a large feature, they went well beyond their training and experience, rendering the embankment vulnerable to failure. When the embankment did breach, the aesthetic enhancement, easy access and other benefits of a large volume of water, such as additional fish protein, were lost. $^{21}$ The political ramifications would likely have been substantial, contributing to the pressure to return the capital to Angkor.

Yet, while the water-retention structure at Koh Ker had many flaws, these could have been remedied. A simple and more sustainable remedy after the embankment was overtopped the first time could have been to enlarge the effective width of the northern chute by, say, a factor of five, or to lower the crest of the main spillway by about a meter to the same level as the spillway in the chute. This should have increased the capacity substantially, making it highly unlikely that the embankment would have been overtopped in subsequent years. This work could have been initiated and completed before the next rainy season at moderate cost. It is unclear when it became apparent that the capacities of the outlets were too small. If the first overtopping was simply at an

\footnotetext{
${ }^{21}$ It is possible that some kind of low-level reservoir was built afterwards (Supporting Information SI 5).
}

inadvertent low point of the embankment at or below $70 \mathrm{~m}$ ASL, significantly lower than the $70.6 \mathrm{~m}$ ASL at the top of the walls of the chute, it may be that no quick and relatively cheap steps were taken to enlarge the outlets, perhaps because they were judged to have functioned satisfactorily at that time without serious damage. Instead, the decision, which seems to have been taken - to leave the outlets as they were but increase the level of the crest by something like a meter - would have been a much more costly and perhaps longer exercise, and appears to have been incomplete by the time the waters of the reservoir rose to overtop the embankment a second time.

The scale and form of works needed to augment the capacity of the spillway and to make it more resistant to erosion should have been sufficiently large for us to determine that because we cannot see any, there were none. It follows that the first overtopping of the northwestern embankment was probably at a level at or below $70 \mathrm{~m}$ ASL, a height sufficiently low to avoid significant damage to the spillway.

It would have been a straightforward exercise for the royal engineers to compare the water height along the length of the embankment with the level of the tops of the chute and the spillway walls, and calculate how much the different sections needed to be raised. Given the workforce available to Jayavarman IV, this could have been completed within one or two dry seasons, or indeed within months. Since this work was not completed, we expect that the second overtopping occurred within a couple of years of the first.

The inflows to the reservoir needed to overtop an embankment at $70.6 \mathrm{~m}$ (or even $70.3 \mathrm{~m}$ ) appear to be significantly greater than those observed locally today. Nevertheless, the thunderstorms to produce such flows in this Cambodian catchment appear reasonably feasible.

A scenario that does not require there to have been a possibly rare thunderstorm is that the crest of the embankment settled to around $70 \mathrm{~m}$ ASL at the points of the first overflow and erosion. If the embankment had not been properly maintained, it is quite feasible that fill of about $2^{1 / 2} \mathrm{~m}$ settled half a meter, so that it was easily overtopped a second time within a year or so. Such an event is consistent with the breaches at Point 1 being at the same location on both occasions. Alternative scenarios for overtopping at $70.6 \mathrm{~m} \mathrm{ASL}$, while feasible, appear to be less likely.

One of the key constraints on the success of early societies and their settlements in monsoon Southeast Asia would have been their ability to manage water effectively and mitigate the consequences of the seasonal 
availability of water and hydroclimatic instability at the annual scale or greater (Buckley et al., 2010). It is often argued in the literature that Angkorian kings had complete mastery over the natural environment, and that as a result of their "engineering genius" their water control systems worked highly effectively (e.g. (Engelhardt, 1995)). Proponents of this view commonly point to the lack of evidence for failure of the hydraulic structures during the Angkor period (Peou et al., 2016, 145), the implication being that failure of the system occurred after the abandonment of Angkorian cities as capitals, or was due to some exogenous factor such as excess flooding resulting from deforestation (Groslier, 1979; Groslier, 2007).

An increasing body of evidence, however, shows that many of the great hydraulic works of the Angkorian world were subject to episodes of failure and renewal during the Angkorian period (Lustig, 2012; Penny, 2014; Penny et al., 2014; Penny et al., 2007[2005]), a conclusion that is well-supported by the data presented here. It now seems clear that there were inherent tensions between politico-religious imperatives and good engineering practice in the construction of Angkorian water management systems, which substantially diminished their overall effectiveness and sustainability. This was apparently compounded, in the case of Koh Ker, by inexperience in the construction of vast hydraulic works far removed from the seasonally inundated lowlands that were the traditional homeland of the Khmer.

\section{Acknowledgements}

This work was funded by the Graduate Research Support Grant, Graduate and Professional Student Association, the Office of Graduate Education, the Office of the Vice President for Research and Economic Affairs, and the Graduates in Integrative Society and Environmental Research (GISER) Research Seed Fund at Arizona State University. The authors also received financial support from the Australian Research Council (grant \#DE160100703), the APSARA National Authority, the University of Sydney, the Rust Family Foundation, the National Science Foundation (Dissertation Improvement Grant 1638137), and the European Research Council (ERC) under the European Union's Horizon 2020 research and innovation programme (grant agreement No. 639828). Acquisition of the airborne laser scanning data was co-sponsored by partners in the Khmer Archaeology Lidar Consortium.

We wish to acknowledge the continuing help of the APSARA National Authority and the National Authority of Preah Vihear. We extend our thanks to the Field Crews of 2013, 2014, 2015 and 2016, and appreciate the invaluable help of Kyle Latinis and his 2015 and 2016 Koh Ker Field Schools, as well as the Cambodian Mine Action Centre. We are grateful for the assistance in the field of Arun Akella, Chet Chap, Stéphane De Greef, Kong Leaksmy, Lunh Lay, Shaun Mackey, Set Ry, So Malay, Suy Pov, Tho Thon and Nick Wiggins. Lim Srey supplied the rainfall data for Siem Reap. Barry le Plastrier undertook the initial hydraulic modeling, while Geoff O'Loughlin advised on the use of HEC-RAS and HEC-GeoRAS. Andrew Wilson provided information on the archaeological investigations at Bam Penh Reach.

Alain Protat supplied information on thunderstorms at Darwin, and Ed Zipser accessed satellite data from TRMM, the Tropical Rainfall Measuring Mission. Ichita Shimoda provided the pluviometric data collected by the Japanese Government Team for Safeguarding Angkor (JSA). Matti Kummu helped us obtain the DIAS data through the Mekong River Commission. The DIAS data set is archived and provided under the framework of the Data Integration and Analysis System (DIAS, DIAS-P), through the National Key Technology, Marine Earth Observation Exploration System.

The SRTM data was obtained from the Land Processes Distributed Active Archive Center (LP DAAC), located at USGS/EROS, Sioux Falls, SD. http://pdaac.usgs.gov, while the wind data for Siem Reap Airport was supplied by the Iowa Environmental Mesonet. Aedeen Cremin gave valuable advice in her review of this article prior to its submission for publication.

\section{Appendix A. Supplementary data}

Supplementary data to this article can be found online at https:// doi.org/10.1016/j.jasrep.2017.11.014.

\section{References}

Ackerman, C.T., 2012. HEC-GeoRAS: GIS Tools for Support of HEC-RAS using ArcGIS User's Manual. US Army Corps of Engineers, H. E. C. H, Davis.

Buckley, B.M., Anchukaitis, K.J., Penny, D., Fletcher, R., Cook, E. R., Sano, M., Le, C.N., Wichienkeeo, A., Ton, T.M., Truong, M.H., 2010. Climate as a contributing factor in the demise of Angkor, Cambodia. Proc. Natl. Acad. Sci. U. S. A. 107 (15), 6748-6752.

CGIAR-CSI SRTM 90m Digital Elevation Database v4.1. Available online: http://srtm.csi. cgiar.org [Accessed 2016].

Chanson, H., 2004. The Hydraulics of Open Channel Flow : an Introduction: Basic Principles, Sediment Motion, Hydraulic Modelling, Design of Hydraulic Structures. Elsevier, Oxford.

Chen, Y.D., Chappell, N.A., 2009. Climate regulation of Southeast Asian hydrology. In: Snidvongs, L.L., Chen, C.-T.A., Daniel, R. (Eds.), Critical States: Environmental Challenges to Development in Monsoon Southeast Asia. Strategic Information and Research Centre, Kuala Lumpur, pp. 205-220.

Coastal Engineering Research Center, 1984. Shore Protection Manual, 1 and 2. 2 vols Department of the Army, Washington DC.

Cœdès, G., 1931. Études cambodgiennes. XXV, Deux inscriptions sanskrites du Fou-nan. XXVI, La date de Kôh Ker. XXVII, La date du Bàphûon. Bulletin de l'École française d'Extrême-Orient 31, 1-23.

Cœdès, G., 1937. Inscriptions du Cambodge. Collection de textes et documents sur l'Indochine, vol. I, 8 vols. École française d'Extrême-Orient, Paris.

Codès, G., 1953. Inscriptions du Cambodge. Collection de textes et documents sur l'Indochine, Vol. V, 8 vols. École française d'Extrême-Orient, Paris.

Codès, G., 1954. Inscriptions du Cambodge. Collection de textes et documents sur l'Indochine, Vol. VI, 8 vols. École française d'Extrême-Orient, Paris.

Conyers, L.B., 2013. Ground-penetrating Radar for Archaeology. Rowman and Littlefield, Lanham.

DIAS, 2010. APHRODITE's Water Resources (Asian Precipitation - Highly Resolved Observational Data Integration Towards Evaluation of Water Resources): Monsoon Asia Precipitation Data. Available online: http://www.chikyu.ac.jp/precip/ [Accessed 4th November 2013 and 5th April 2017].

Engelhardt, R.A., 1995. Two thousand years of engineering genius on the Angkor Plain (Cambodia). Expedition 37 (3), 18-29.

Evans, D., 2010-2011. The Archaeological Landscape of Koh Ker, Northwest Cambodia. Bulletin de l'École française d'Extrême-Orient 97-98, 91-150.

Evans, D., Pottier, C., Fletcher, R., Hensley, S., Tapley, I., Milne, A., Barbetti, M., 2007. A comprehensive archaeological map of the world's largest preindustrial settlement complex at Angkor, Cambodia. Proc. Natl. Acad. Sci. U. S. A. 104 (36), 14277-14282.

Evans, D., Fletcher, R., Pottier, C., Chevance, J.-B., Soutif, D., Tan, B.S., Im, S., Ea, D., Tin, T., Kim, S., Cromarty, C., De Greef, S., Hanus, K., Bâty, P., Kuszinger, R., Shimoda, I., Boornazian, G., 2013. Uncovering archaeological landscapes at Angkor using lidar. Proc. Natl. Acad. Sci. U. S. A. 110 (31), 12595-12600.

Finch, J., Calver, A., 2008. Methods for the Quantification of Evaporation From Lakes: Prepared for the World Meteorological Organization's Commission for Hydrology. Centre for Ecology and Hydrology. Centre for Ecology and Hydrology, Wallingford.

Fletcher, R., Pottier, C., Evans, D., Kummu, M., 2008. The development of the water management system of Angkor: A Provisional Model. IPPA Bull. 28, 57-66.

Goddard Space Flight Center, 2016. TRMM: Tropical Rainfall Measuring Mission. Available online. https://trmm.gsfc.nasa.gov [Accessed 2017].

Groslier, B.-P., 1979. La cité hydraulique Angkorienne. Bulletin de l'Ecole française d'Extrême-Orient 66, 161-202.

Groslier, B.-P., 2007. The Angkorian hydraulic city: exploitation or over-exploitation of the soil? Aséanie 20, 141 (translated from the French by T. Lustig and C. Pottier).

Hansen, E., 1968-1969. Cambodge: Aménagement du Phnom Kulen. UNESCO, Paris.

Hendrickson, M., 2007. Arteries of empire: an operational study of transport and communication in Angkorian Southeast Asia (9th to 15th centuries CE) (Ph.D.) University of Sydney.

Hewlett, H.W.M., Boorman, L.A., Bramley, M.E., 1987. Design of Reinforced Grass Waterways. Construction Industry Research and Information Association, London.

Iowa Environmental Mesonet, 2001-2017. ASOS Network. Available online: https:// mesonet.agron.iastate.edu/request/download.phtml?network $=\mathrm{KH} \_$ASOS [Accessed March 8 2017].

Jacques, C., 1971. Sur les données chronologiques de la stèle de Tûol Ta Pec (K. 834) Bulletin de l'Ecole française d'Extrême-Orient. 58, 163-176.

Jacques, C., 2014. Koh Ker: Temples et inscriptions, avec une étude sur le roi Jayavarman IV et un essai sur $\mathrm{l}^{\prime}<<$ esclavage $>>$ dans l'ancien pays khmer. Hungarian Southeast Asian Research Institute, Budapest.

JSA, 2000. Rain_Prasat Suor Prat JSA. Excel Spreadsheet. Japanese Government Team for Safeguarding Angkor. Waseda University.

Langbein, W.B., 1960. Plotting positions in frequency analysis. In: Dalrymple, T. (Ed.), Flood-frequency Analyses; Manual of Hydrology: Part 3. Flood-flow Techniques. Geological Survey Water-Supply Paper 1543-A U.S. Government Printing Office, Washington, pp. 48-51.

Lustig, T., 2012. Linking downstream to upstream in Landscape Archaeology - two Southeast Asian examples. In: Bonatz-Tjoa, M.L., Reinecke, A., Bonatz, D. (Eds.), Connecting Empires and States: Selected Papers from the 13th International Conference of the European Association of Soutehast Asian Archaeologists. NUS 
Press, Singapore, pp. 209-225

Nobuhiro, T., Shimizu, A., Tanaka, K., Tamai, K., Kabeya, N., Ito, E., Shimizu, T., Araki, M., Chann, S., 2009. Evapotranspiration characteristics of a lowland dry evergreen forest in Central Cambodia examined using a multilayer model. J. Water Resour. Prot. 1, 325-335.

Penny, D., 2014. Social upheaval in ancient Angkor resulting from fluvial response to land use and climate variability. Pages Mag. 22 (1), 32-33.

Penny, D., Pottier, C., Kummu, M., Fletcher, R., Zoppi, U., Tous, S., 2007. Hydrological history of the West Baray, Angkor, revealed through palynological analysis of sediments from the West Mebon. Bulletin de l'École Française d'Extrême-Orient 92, 497-521.

Penny, D., Chevance, J.-B., Tang, D., De Greef, S., 2014. The environmental impact of Cambodia's ancient city of Mahendraparvata (Phnom Kulen). PLoS One 9 (1), 1-9 (e84252).

Peou, H., Natarajan, I., Hong, T., Philippe, D., 2016. From conservation to sustainable development-a case study of Angkor World Heritage Site, Cambodia. J. Environ. Sci. Eng. A (5), 141-155.
Peters, J.M., Schumacher, R.S., 2015. Mechanisms for organization and echo training in a flash-flood-producing mesoscale convective system. Mon. Weather Rev. 143, 1058-1085.

Rouse, H., 1947. Elementary Mechanics of Fluids. John Wiley and Sons, New York. Scharffenberg, W., 2012. Hydrologic modeling system HEC-HMS, Version 4.2: User's Manual [eBook]. US Army Corps of Engineers, Hydrologic Engineering Center (HEC), Davis [Accessed September 2017].

Shimoda, I., Sato, K., 2009. Religious concept in the layout of the ancient Khmer city of Koh Ker. Udaya J. Khmer Stud. 10, 25-55.

Vickery, M., 1986. Some remarks on early state formation in Cambodia. In: Hall, D.G., Milner, A.C. (Eds.), Southeast Asia in the 9th to 14th Centuries. Institute of Southeast Asian Studies, Singapore, pp. 95-115.

Warner, J.C., Brunner, G.W., Wolfe, B.C., Piper, S.S., 2009. HEC-RAS, River Analysis System Applications Guide. Davis, US Army Corps of Engineers Hydrologic Engineering Center (HEC).

Washington State Department of Transport, 2013. WSDOT Geotechnical Design Manual. Washington State Department of Transport, Olympia. 